\title{
EL CONTROL DE CONSTITUCIONALIDAD DE OFICIO EN LA JURISPRUDENCIA DE LA CORTE SUPREMA DE JUSTICIA ARGENTINA
}

\author{
VICTOR BAZAN \\ Catedrático de Derecho Constitucional de la Facultad de Derecho \\ y Ciencias Sociales de la Universidad Católica de Cuyo, \\ San Juan, República Argentina.
}




\section{SUMARIO}

I. Preliminar. II. Sustento de la tesis proscriptiva. III. Nuestra posición: FUNDAMENTOS PARA POSTULAR LA INSTITUCIONALIZACIÓN DEL CONTROL DE CONSTITUCIONALIDAD DE OFICIO: 1. Una cuestión de derecho. 2. Enseñanzas del derecho comparado de las Provincias y de la Ciudad Autónoma de Buenos Aires. 3. Supremacia constitucional y pauta iura novit curia. 4. Naturaleza y calibre de la presunción de validez de las normas y actos estatales. 5. Alcance y proyección del debate jurisdiccional sobre la razonabilidad de las normas. IV. LA LíNEA EVOLUTIVA DE LA JURISPRUDENCIA DE LA CORTE SOBRE EL CONTROL DE CONSTITUCIONALIDAD EX OFFICIO: 1. Pórtico. 2. Tesis prohibitiva. 3. Algunos precedentes o votos refrescantes. V. LA CAUSA "MiLl de Pereyra, Rita AuRORA Y otros C/ Provincia de Corrientes». VI. SOBRE LAS MUTACIONES EN LA CONFORMAción de la Corte lUego de "Mill de Pereyra». VII. Observaciones finales. 


\title{
EL CONTROL DE CONSITUCIONALIDAD DE OFICIO EN LA JURISPRUDENCIA DE LA CORTE SUPREMA DE JUSTICIA ARGENTINA
}

\author{
POR \\ VICTOR BAZÁN \\ Catedrático de Derecho Constitucional de la Facultad de Derecho \\ y Ciencias Sociales de la Universidad Católica de Cuyo, \\ San Juan, República Argentina
}

\section{PRELIMINAR}

Comenzaremos advirtiendo que si bien hasta el caso "Mill de Pereyra» 1 ( $y$, como veremos, con una mayoría sui generis) la Corte Suprema de Justicia de la Nación len adelante: la Corte o la Corte Suprema] no se había expedido abiertamente - salvo algunas excepciones- en favor de la viabilidad del control de constitucionalidad de oficio, ya antes de aquella causa comenzó a patentizar ciertos signos que permitían inferir que dicha posibilidad terminaría por imponerse, pues -inter alia - habia emitido algunos fallos que suavizaban la fuerte exigencia otrora indispensable de introducir el caso federal o constituciona $\mathbb{R}$ (también conocido como cuestión constitucional o federah en ocasión de la primera oportunidad procesal con que contaba el recurrente.

1 Sentencia del 27 de setiembre de 2001, sobre la cual volveremos:

2 Como recuerda BIDART CAMPOS, el caso federal constituye el tronco vertebral del recurso extraordinario, y puede ser conceptuado como una cuestión de derecho en la 
Sin pretensión alguna de exhaustividad, en el presente trabajo intentaremos pasar revista a la evolución jurisprudencial que en esta materia (control de constitucionalidad ex officio, principalmente, en el contexto del recurso extraordinario) ha experimentado la Corte $y$, también, dejar sentada nuestra posición personal en favor de la necesidad de superar definitivamente vetustas concepciones que niegan andamiento a tal modalidad de fiscalización constitucional, al tiempo que vehiculan injustificadas (auto)detracciones a la labor de la magistratura jurisdiccional, cuando de velar por el mantenimiento de la supremacía constitucional se trata.

No es dable soslayar al respecto que, como recuerda Morello, la Corte coloca en el primer plano de su alta misión la función de salvaguarda de dicha supremacía de la Constitución y sus principios, ejerciendo la jurisdicción extraordinaria que le incumbe -subrayado del original-(Fallos, 204:474) ${ }^{3}$. En sintonía, SAGÜÉS recuerda que la segunda meta histórica del recurso extraordinario, aunque primera desde el punto de vista conceptual, consiste en la idea de cifrar como cometido esencial la defensa de la Constitución Nacional por encima de normas y actos federales o provinciales 4.

A modo de deslinde conceptual, consignamos que a la expresión "control de constitucionalidad de oficio" se le asignará en el presente la significación de contralor ejercitable sin petición de parte, mas en el contexto de un proceso judicial, lo que, en la terminología de SAGÜÉs 5 , supondría la declaración de oficio en sentido total.

que directa o indirectamente esté comprometida la Constitución federal, sea en su interpretación o en su supremacía (BIDART CAMPOS, Germán J.: Tratado Elemental de Derecho Constitucional Argentino, $\mathrm{T}^{\circ}$ II ["El Derecho Constitucional del poder"], nueva ed. ampl. y actualiz., Ediar, Buenos Aires [en adelante: Bs. As.], República Argentina [en lo sucesivo: Rep. Arg.l, 1993, pág. 638).

3 Morello, Augusto M.: La Nueva Etapa del Recurso Extraordinario. El "certiora$r^{\prime \prime}$ (Ley 23.774), Libr. Edit. Platense - Abeledo-Perrot, Bs. As., Rep. Arg., 1990, págs. 3/4.

4 Señala el aludido autor que la mutación fundamental de los fines del recurso extraordinario (cuando se lo destina no sólo para defender al Estado federal ante las provincias o Estados locales, sino también para mantener la supremacía constitucional frente a las sentencias de los propios tribunales federales $y$ frente a las leyes que dicta el Congreso federal) está perfectamente enunciada, por ejemplo, en "Basombrio" (Fallos, 256:376) y en "Manzoratte c/ Provincia de Buenos Aires" (Fallos, 280:228). Para la referencia que se realiza en el texto y la que se vuelca en la presente nota, vid. SAGüEs, Néstor P.: Derecho Procesal Constitucional [Recurso extraordinario], $T^{\circ} 1,2^{\mathrm{a}} \mathrm{ed}$. actualiz. y ampl., Astrea, Bs. As., Rep. Arg., 1989, págs. 309 y 308.

5 Es la hipótesis en la que el magistrado toma tal decisión cuando no media petición alguna de parte; la declaración de oficio en sentido parcial, para el autor rosarino, 
La aclaración terminológica recepta justificación en nuestro intento por sortear la ambivalencia semántica que permite considerarlo también como control en abstracto o al margen de causa judicial, ámbito que sería jurisdiccionalmente impenetrable vis-à-vis lo previsto por el art. 2 de la Ley Nac. $\mathrm{N}^{\circ} 27^{6}$, que dispone que la justicia nacional «nunca procede de oficio y sólo ejerce jurisdicción en los casos contenciosos en que es requerida a instancia de parte». Nos parece que la apuntada es la verdadera télesis del precepto, ya que en éste no hay nada que permita inferir la existencia de una prohibición para el advenimiento del control constitucional sin petición de parte en una causa concreta, pues lo que se procura es que los tribunales federales no actúen por medio de decisiones genéricas, en abstracto, sino ante litigios concretos sustentados en intereses adversos de las partes $^{7}$.

\section{SUSTENTO DE LATESIS PROSCRIPTIVA}

Para comenzar a delinear los contornos del problema con el que nos enfrentamos, corresponde rememorar que la base de sustentación de la prohibición autoimpuesta por la Corte en cuanto a la declaración de

se configuraría cuando, existiendo requerimiento de parte, el juez se pronuncia estimatoriamente empleando un argumento no esgrimido por tal postulante (SAGüÉs, Néstor P.: "El control de constitucionalidad de oficio. Alternativas normativas en Argentina: Prohibición, facultad o deber", El Derecho [Suplemento de Derecho Constitucional], diario del 18/03/99, Bs. As., Rep. Arg., pág. 1).

6 Palacio y Alvarado Velloso verifican que la Ley Nac. $N^{\circ} 48$, modificando la Ley Nac. $\mathrm{N}^{\circ} 27$-citada en el texto- e inspirándose, como esta última, en la Judiciary Act norteamericana del 24 de setiembre de 1789 (sección 25), instituyó -para hacer efectiva la competencia discernida en la Corte Suprema de Justicia de la Nación por el art. 116 de la Constitución Nacional (conocimiento y decisión de todas las causas que versen sobre puntos regidos por ésta)- un recurso de "apelación" que la práctica y la legislación posteriores denominaron simplemente "recurso extraordinario", encaminado principalmente a la preservación de la supremacía constitucional (PALACIO, Lino Enrique y Alvarado Velloso, Adolfo: Código Procesal Civil y Comercial de la Nación, $\mathrm{T}^{\circ} 6^{\circ}$, Rubinzal-Culzoni, Santa Fe, Rep. Arg., 1992, pág. 226).

7 Ver la referencia que formula Morello, Augusto M.: La Corte Suprema en acción, Libr. Edit. Platense - Abeledo-Perrot, Bs. As., Rep. Arg., 1989, págs. 421/422. El citado autor alude a un fallo de la Cámara Federal Penal de La Plata, Sala III, de marzo de 1988, por el que se declaró de oficio la inconstitucionalidad del art. 6 de la Ley Nac. $N^{\circ} 20.771$ (con voto del Dr. Schiffrin y adhesión fundada del Dr. Garro). 
inconstitucionalidad de oficio ( $y$, por extensión, algo más que subliminalmente transmitida a los magistrados inferiores) se concentra -en líneas generales - en las siguientes pautas 8 :

- La acechanza del peligro de absorción de los poderes ejecutivo y legislativo por el judicial, con el consecuente demérito del equilibrio de los poderes del Estado;

- que tal hipótesis de contralor constitucional atentaría contra la presunción de validez de los actos estatales;

- que podría provocar la vulneración del derecho de defensa en juicio de las partes; $y$

- que resulta insoslayable la existencia de un perjuicio para la parte que acusa la inconstitucionalidad de la norma, por lo que - si no convergiera tal petición de parte - se presumiría la inexistencia del mentado daño, bloqueándose la posibilidad de ejercer el control constitucional.

\section{NUESTRA POSICIÓN: FUNDAMENTOS PARA POSTULAR LA INSTITUCIONALIZACIÓN DEL CONTROL DE CONSTITUCIONALIDAD DE OFICIO ${ }^{9}$}

\section{Una cuestión de derecho}

En primer lugar, corresponde advertir que la declaración de inconstitucionalidad es una cuestión de derecho y no de hecho, por lo que su resolución de oficio no quiebra la igualdad de las partes en el proceso ni afecta la garantia de defensa en juicio, la que no podría ser argüida frente al derecho aplicable ${ }^{10}$ para dirimir la contienda.

8 Cftar. SAGüÉs, Néstor P.; op. cit. [Derecho Procesal...], pág. 133.

9 Ver, por ejemplo, de BAZÁN, Víctor: “El control de constitucionalidad de oficio en el ámbito federal argentino y la necesaria superación de una inadecuada concepción jurisdiccional", Foro de Córdoba, Año XI, N 62, Córdoba, Rep. Arg., 2000, págs. 31/47; "Un debate recurrente: ¿Es sustentable la posición de la C.S.J.N. en el sentido de proscribir el ejercicio jurisdiccional del control de constitucionalidad de oficio?, Entre Abogados, Año VIII, N 1, 2000, Foro de Abogados, San Juan, Rep. Arg., págs. 21/35.

10 BidaRt CAmpos, Germán J.: Manual de la Constitución reformada, T III, Ediar, Bs. As., Rep. Arg., 1997, pág. 439. 
Asimismo, y si de la declaración ex officio se predicara algún menoscabo a la aludida garantía, debería también descalificarse cualquier aplicación de una norma infraconstitucional que el juez hiciera sin que hubiese mediado petición de los litigantes, pues emergería la excusa de que los interesados no fueron oídos respecto de la utilización de aquélla en el caso concreto ${ }^{11}$.

Además, la aludida declaración oficiosa no implica fallar extra petita ni soslayar el principio de congruencia, en tanto el juez se atiene a las cuestiones planteadas y a las circunstancias fácticas invocadas en el proceso y, para dilucidar la litis, sólo sujeta la selección del derecho aplicable a su concordancia con la Ley Fundamental, tarea en la que válidamente podria moverse con independencia de las pretensiones de las partes ${ }^{12}$.

Es que, como con acierto se ha dicho, "la mera voluntad de las partes no puede corregir la incompatibilidad de una norma no constitucional con la fundamental, primera y mayor resultante de la voluntad colectiva»13. Parafraseando a LINARES, podría conjeturarse que la ley o el acto administrativo sujetos a contralor constitucional pueden tener fundamento de existencia (en cuanto fueron dictados y hacen parte del derecho vigente) y fundamento de esencia (desde que se apoyan en normas jurídicas), pero carecer del fundamento de razonabilidad por resultar injustos ${ }^{14}$; y es alli donde debe patentizarse el control a su respecto (una vez verificada la injusticia que evidencian), aun cuando los restantes fundamentos resulten teórica u objetivamente cumplidos.

11 Cfr. disidencia de Fayt y Belluscio (considerando $5^{\circ}$ ), in re: "Juzgado de Instrucción Militar N 50 de Rosario", del 24 de abril de 1984 (Fallos, 306:303, específicamente, ver pág. 315).

Volveremos sobre tal precedente, aunque aclaramos que la importancia del mismo no reside en la solución propiciada por la mayoría que terminó por imponerse, sino en la brillante fundamentación que brindaron los mencionados ministros que votaron en disidencia.

12 BIDART CAMPOS, Germán J.: La interpretación y el control constitucionales en la jurisdicción constitucional, Ediar, Bs. As., Rep. Arg., 1987, pág. 155.

13 Del voto minoritario (del doctor Ghione) expedido por la Suprema Corte de la Provincia de Buenos Aires en la causa "Olivera, Enrique" (del 29 de setiembre de 1992), Jurisprudencia Argentina, T 1993-II, Bs. As., Rep. Arg., págs. 208 y ss., especialmente, pág. 212.

14 LinARES, Juan Francisco: Razonabilidad de las leyes. El 'debido proceso' como garantía innominada en la Constitución Argentina, $2^{\mathrm{a}}$ ed. actualiz., $1^{\mathrm{a}}$ reimpr., Astrea, Bs. As., Rep. Arg., 1989, pág. 108. 
Todo ello, sin olvidar que el control de constitucionalidad no es una concesión graciosa conferida a los jueces, sino - a la par que atribuciónun deber que sobre los mismos se cierne en pro de mantener la incolumidad jerárquica de la Ley Fundamental.

2. Enseñanzas del derecho comparado de las Provincias y de la Ciudad Autónoma de Buenos Aires

llustrativamente, consignamos que en éste, como en otros aspectos, el derecho público comparado de las Provincias y de la Ciudad Autónoma de Buenos Aires ofrece interesantes aportes. Veamos:

A. En efecto, la Constitución de San Juan prescribe en su art. 11 que "toda ley, decreto, ordenanza o disposición contraria a la Ley Suprema de la Nación o a esta Constitución, carecen de valor y los jueces deben deciarar su inconstitucionalidad en juicio, aun cuando no hubiere sido requerido por parte, previo conocimiento a las mismas..." [bastardilla nuestra].

Cabe aclarar que durante las labores de la Convención Constituyente el despacho primigenio de la mayoría (perteneciente al radicalismo) proyectaba un traslado previo a las partes, lo que en el debate fue sustituido por la redacción actual que exige el previo conocimiento de aquéllas. De cualquier modo, intuimos en la redacción de tal tramo de la norma una perceptible influencia de VANOSSI, quien -si bien partidario de la declaración de inconstitucionalidad ex officio-, propugnaba la necesidad de que el juez interviniente corriera un traslado a las partes acerca de la constitucionalidad o inconstitucionalidad de la norma en juego; ello, como medida para mejor proveer $y$ en orden a prevenir un potencial planteamiento relativo a la vulneración del derecho de defensa de ellas ${ }^{15}$.

A modo de comentario colateral, valga rememorar que en el curso de las sesiones de la Convención surgieron interesantes debates relativos a la conformación léxica del art. 11 y a la viabilidad del control jurisdiccional de constitucionalidad de oficio. Sintéticamente, valga aclarar que quedaron evidenciadas dos posiciones claramente marcadas:

15 En el año 1985, mientras se desempeñaba como diputado nacional por la Capital Federal, VANOSSI presentó -entre otros- un proyecto de ley que tendía a modificar el art. 3 de la Ley Nac. $N^{\circ} 27$, cuyo objetivo era consagrar el control de constitucionalidad de oficio, incluyendo el traslado referido en el texto. El autor justifica la existencia de tal traslado diciendo que reconoce como propósito el que las partes "tengan oportunidad de defender su persona y sus derechos en condiciones de igualdad, antes de la sentencia del juez sobre el fondo del asunto" (vid. VANOSSI, Jorge Reinaldo y UBERTONE, Fermín Pedro: "Control jurisdiccional de constitucionalidad", en BAZÁN, Víctor [coordinador]: Desafios del control de constitucionalidad, Ediciones Ciudad Argentina, Bs. As., Rep. Arg., 1996, pág. 93). 
a) Una de ellas, encabezada por el convencional Acosta (del bloquis$\mathrm{mo})$, se mostraba reticente a tal modalidad de contralor -en tesis que no compartimos-, fundándose en que la misma podría entrañar la violación del derecho de defensa en juicio, para pasar a pronunciarse en favor de mantener el statu quo programado por la fenecida Constitución de 1927, que disponía expresamente la necesidad del requerimiento de parte ${ }^{16}$. Sin embargo, justo es reconocer que sí acordamos con la crítica que el aludido convencional efectuó al hasta ese momento exigible traslado a las partes ${ }^{17}$, que - como anunciábamos - proyectaba la norma en su redacción original. Al respecto, además de los reparos que desde el punto de vista sustancial nos provoca la exigencia de un traslado a las partes o -como en el caso de la Constitución sanjuanina - el previo conocimiento de ellas (ya que el control de constitucionalidad es una cuestión de derecho y no de hecho), tampoco quedan procesalmente en claro los siguientes aspectos - presentados ejemplificativamente-: ¿Qué significa el mentado conocimiento?; ¿qué alcances tendrá?; el decreto judicial que lo dispone, ¿será recurrible?; la comunicación a las partes, ¿no entrañará un tipo de prejuzgamiento por parte del magistrado actuante?; además de inquirirnos - entre otras cuestiones-, ¿qué sucedería en caso de que ambas partes se opusieran a la potencial declaración de inconstitucionalidad de la norma de marras? En tal caso, ¿se privilegiará la expresa intención de los litigantes o, por el contrario, primará una eventual convicción judicial acerca de la necesidad de descalificar la norma por su repugnancia con la Constitución? Aquella voluntad convergente de las partes, ¿no ejercerá alguna presión subliminal en el juez, persuadiéndolo de la inconveniencia de descartar la norma no obstante el deber constitucional sobre él discernido?

b) Volviendo de la digresión, y para continuar con la síntesis de las posturas evidenciadas durante el proceso constituyente reformador, valga evocar que la posición de la mayoría - que naturalmente prevaleció- preconizaba la institucionalización del examen constitucional de oficio, pues

16 Diario de Sesiones de la Honorable Convención Constituyente, $4^{\mathrm{a}}$ sesión, reunión $\mathrm{N}^{\circ} 7,19 / 03 / 86$, pág. 267. Concretamente se refiere al art. 117 , inc. $2^{\circ}$, de la Constitución de 1927, que establecia que corresponde a la Corte de Justicia y demás tribunales inferiores, el conocimiento y decisión "de las causas acerca de la constitucionalidad o inconstitucionalidad de las leyes, decretos y reglamentos que estatuyan sobre materia regida por esta Constitución y se controvierta por parte interesada" énfasis propio-.

17 idem. Tal cuestionamiento fue igualmente sostenido (a nuestro criterio, sobre bases pragmáticas y realistas) por el convencional bloquista Rizo (ibíd., págs. 271) y que provocara un leve estado dubitativo en el convencional Moncunill, éste de la propia mayoría radical (ibíd., pág. 270). 
- como lo indicó el convencional Figueroa - la declaración de inconstitucionalidad no es una atribución del poder judicial, sino un deber ínsito a cargo de éste ${ }^{18}$, además de puntualizar - entre otros argumentos-que tal declaración «o la congruencia constitucional no puede quedar supeditad[a] a la mayor perspicacia o no de los litigantes que intervienen en el proceso [ya que] la cuestión constitucional atiende al orden público y por tanto es irrenunciable, no podría suponerse que aquel individuo que no pidió la declaración de inconstitucionalidad, hizo renuncia a ese derecho» ${ }^{19}$. Hoy, a más de dieciséis años de proferidas, no podemos sino coincidir con la concepción jurídica subyacente en tales afirmaciones.

B. Continuando con la reseña propuesta, la Constitución de La Rioja prevé que el deber de declaración de inconstitucionalidad se efectivizará a requerimiento de parte o de oficio (art. 9), complementando tal previsión con lo dispuesto en el art. 132 ibíd., en el que se entroniza el deber judicial de mantener la supremacía constitucional, enfatizando - acertadamente a nuestro juicio- que el control de constitucionalidad es una cuestión de derecho 20 .

C. A su turno, normativa sustancialmente similar a la riojana ofrece la Constitución de San Luis, a través de la interacción de sus arts. 10 y 210 .

D. Por su parte, la Ley Fundamental de Río Negro establece en su art. 196 , párrafo $2^{\circ}$, como una de las funciones del poder judicial la de verificar la constitucionalidad de las normas que aplica, a pedido de parte o de oficio.

E. A su tiempo, la Norma Mayor de Tierra del Fuego señala que el poder judicial verificará, a pedido de parte o de oficio, la constitucionalidad de las normas que aplique (art. 154, anteúltimo párrafo).

F. Por último, y en su art. 14, la Constitución de la Ciudad Autónoma de Buenos Aires (C.C.A.B.A.)21, más allá de reproducir la primera parte del párrafo $1^{\circ}$ del art. 43 de la Constitución Nacional [en adelante: C.N.], ha estableci-

18 Ibíd., pág. 269. Recibió apoyo, también, de parte del convencional Ramella -de la bancada del FREJULI- (ibíd., pág. 270).

19 lbíd., pág. 270.

20 Valga resaltar que la reciente reforma constitucional riojana (concretada durante 2002) ha mantenido la redacción de ambas normas.

21 Para éste y otros temas conectados con la C.C.A.B.A., ver los siguientes trabajos de BAZÁN, Víctor: "Posibles vías de corrección de las omisiones inconstitucionales en los ámbitos del derecho público de la Ciudad Autónoma de Buenos Aires y provincial argentino", en FERRER MAC-GREGOR, Eduardo [coordinador]: Derecho procesal constitucional, $3^{a}$ ed., $T^{\circ}$ III, Colegio de Secretarios de la Suprema Corte de Justicia de la Nación, 
do expresamente la gratuidad de la acción de amparo; ha ampliado visiblemente la legitimación activa y la verbalización de las hipótesis de derechos o intereses colectivos (no emplea la expresión 'derechos de incidencia colectiva') que habilitarían, precisamente, el amparo colectivo (art. $14,2^{\circ}$ párrafo) vis-à-vis el párrafo $2^{\circ}$ del art. 43 de la Carta Magna Nacional; para pasar a diseñar una trilogía de pautas que no podemos sino aplaudir: en primer lugar, la innecesariedad de agotar la vía administrativa para la procedencia de la acción (art. 14, párrafo $3^{\circ}$ ); en segundo lugar, que el procedimiento está desprovisto de formalidades procesales que pudieren afectar su operatividad, paralelamente a determinar que todos los plazos son breves $y$ perentorios $y$ a disponer la exención de costas para el accionante, salvo el caso de temeridad o malicia (id. art., párrafo $4^{\circ}$, in fine); y, por fin, el importante aporte que supone facultar a los jueces a declarar de oficio la inconstitucionalidad de la norma en que se funda el acto o la omisión lesivos, superando la estrechez literal del tramo que cierra el párrafo $1^{\circ}$ del art. 43 de la C.N.

En sintonía con ello, y en materia de hábeas corpus, paralelamente a reflejar la preceptiva del art. 43 , párrafo $4^{\circ}$, de la C.N., en un sabio tramo (el final) de su art. 15, la C.C.A.B.A. ha determinado claramente que el juez que entiende en el hábeas corpus puede declarar ex officio la inconstitucionalidad de la norma en que se funden el acto o la omisión lesivos.

G. En torno del tema que examinamos en el presente subapartado22, y como sintetiza BIDART CAMPOS, cuando el derecho provincial brinda habilitación a sus tribunales para ejercer ex officio el control de constitucionalidad, no resultaría de aplicación en la jurisdicción local una jurisprudencia de la Corte Suprema que descalificara tal tipología de contralor 23.

Porrúa, México, D.F., 2002, págs. 2947/2995; “La operatividad de los derechos y las garantías no obstante las omisiones o insuficiencias reglamentarias inconstitucionales", en V.AA.: Instituciones de la Ciudad Autónoma de Buenos Aires, La Ley, Bs. As., Rep. Arg., 2001, págs. 97/128; "La Constitución de la Ciudad de Buenos Aires, ¿estatuto de avanzada o catálogo de deseos?, Entre Abogados, Año IV, № 9, 1996, Foro de Abogados, San Juan, Rep. Arg., págs. 37/40.

22 En posición amplia en cuanto a la potencialidad del ejercicio del control de constitucionalidad de oficio por los tribunales locales, MERCADO LUNA ha manifestado que, teniendo en cuenta que tal contralor se verifica como parte de la faena de la aplicación de la ley, y que los tribunales de provincia aplican tanto las leyes locales, como las nacionales, no parece congruente la discriminación en cuanto a que no les resulte posible controlar la constitucionalidad de las normas nacionales, ya que las leyes que dicta el Congreso de la Nación son para toda la Nación y aplicables por todos los tribunales del país, incluyendo los provinciales, porque las provincias son también la Nación (MERCAdo LUNA, Ricardo: Derecho Constitucional Provincial, Ed. Ciudad Argentina, Bs. As., Rep. Arg., 2000, págs. 191/192).

23 BIDART CAMPOS, Germán J.; op. cit. [La interpretación y el control...], pág. 158. 
Ilustrativamente, reenviamos a lo resuelto por la Corte en "Fernández Valdez, Manuel Guillermo", sentencia del 13 de setiembre de $1988^{24}$, en la que desestimó la queja articulada como consecuencia de la denegatoria del recurso extraordinario deducido contra la sentencia del Tribunal Superior de Justicia de La Rioja que había declarado, de oficio y sobre la base de los mencionados artículos constitucionales locales 9 y 132, la inconstitucionalidad de una ley jubilatoria provincial (concretamente, del art. 3 de la Ley Prov. $N^{\circ} 4.297$ ). Tal tópico no fue censurado por la Corte Suprema, sino convalidado por ésta sobre la base de las facultades de los tribunales provinciales, el alcance de su jurisdicción y la forma en que ejercen su ministerio, todo eilo reglado por las normas constitucionales y legales locales, lo que - según entendió - no es materia revisable en la instancia extraordinaria en razón del respeto debido a la atribución de los Estados provinciales de darse sus propias instituciones y regirse por ellas (Fallos, 301:615) -considerando $3^{\circ}$-.

H. Avanzando un poco más en nuestro análisis, colacionamos un antecedente interesante que denota la incongruencia de la otrora posición dominante del Máximo Tribunal en contra de la viabilidad del control ex officio.

Nos referimos al caso «Dahlgren, Jorge Eric c/ Cáceres, Raúl Edgardo y/o A.T.E.CH.» 25 , en el que la Corte declaró - por mayoría 26 - procedente el recurso extraordinario articulado y dejó sin efecto la sentencia de la Sala Segunda del Superior Tribunal de Justicia de la Provincia de Chaco por la que, no obstante considerar éste que la Ley Prov. $\mathrm{N}^{\circ} 1.272$-modificada por la Ley Prov. $N^{\circ} 1.296-$ establecía una inmunidad gremial penal con categoría parlamentaria constitucionalmente inválida, sostuvo que no podía dejar de aplicar tal normativa en razón de la limitación impuesta por el art. 9 de la Constitución local, que determina la imposibilidad de invadir de oficio facultades propias de otro poder y que tal requerimiento no le había sido efectuado.

Al respecto, la Corte nacional señaló claramente que el Tribunal provincial, al sobredimensionar el interés tutelado por el artículo constitucional 9 y soslayar otros intereses de igual jerarquía, permitió que por una ley

24 Fallos, 311:1855.

25 La sentencia fue emitida el 10 de diciembre de 1996 (ver Fallos, 319:2925).

26 La mayoría estuvo compuesta por Fayt, Belluscio, Boggiano, López y Vázquez. Por su parte, en disidencia conjunta (propiciando la declaración de inadmisibilidad del recurso extraordinario, en mérito al art. 280 del C.P.C.C.N.), lo hicieron Nazareno, Moliné O'Connor y Petracchi. 
local "se consagre una detracción de su función jurisdiccional, no obstante su obligación, por ser cabeza del Poder Judicial provincial, de afirmar y mantener su inviolabilidad $y$ pese a las amplias atribuciones conferidas por el art. 151 de la constitución local para preservar su propia función y su independencia” (considerando $4^{\circ}$ ).

En síntesis, la Corte descalificó el resolutorio por arbitrario toda vez que, «en desmedro de una adecuada hermenéutica de las normas en juego y un exceso ritual manifiesto en su interpretación, el a quo ha[bia] sustentado su fallo en argumentos sólo aparentes con serio menoscabo de las garantías aseguradas por la Constitución Nacional" (considerando 10). La incongruencia 27 y (por qué no) la irrazonabilidad apuntadas al comienzo de este párrafo se patentizan en tanto la Corte, en su voto mayoritario, requirió al Tribunal local una determinada conducta (control de constitucionalidad de oficio) que, paralelamente y ad intra, la mayoría de sus miembros omitía autoexigirse ${ }^{28}$.

\section{Supremacía constitucional y pauta iura novit curia}

Por otra parte, el iura novit curia que a modo de directriz activan los jueces para la orientación y fundamentación de las soluciones jurisdiccionales que expiden, constituye un deber que engloba en su seno al de mantener la supremacía de la C.N. (cfr. art. 31), lo que importa que el juez aplique, en caso de colisión de normas, la de mayor jerarquía (esto es, la

27 En todo caso, y para no perder objetividad en el enfoque, la incongruencia alcanzaba a Boggiano, López y Vázquez, quienes hasta ese momento no se habían expedido aún en favor del control de constitucionalidad de oficio (para una aclaración sobre la posición asumida por López en "Mill de Pereyra", vid. infra nota 87); mientras que Fayt y Belluscio, sí se habían pronunciado expresamente por la viabilidad de aquél.

Por su parte, tampoco cabe predicar incoherencia en Nazareno, Moliné O'Connor y Petracchi (aun cuando sí nuestra discrepancia con la visión que acerca del problema ofrecen), quienes -como vimos- quedaron en minoría en "Dahlgren", propiciando el rechazo del recurso extraordinario e incluso siguieron luego manteniendo una percepción contraria a la procedencia del control de constitucionalidad ex officio, lo que puede constatarse examinando las respectivas posturas que asumieron en "Mill de Pereyra" -ver infra-

$28 \mathrm{Al}$ respecto -y como se pondrá de manifiesto más adelante (subap. V.III.C)- ver la referencia que el propio Vázquez formula en el considerando 18 de su voto concurrente en "Mill de Pereyra".

Compulsar, asimismo, los interesantes trabajos de Gullco, Hernán V.: "La declaración de oficio de inconstitucionalidad en el ámbito federal y provincial", $L a$ Ley, $T^{\circ}$ 1998A, Bs. As., Rep. Arg., págs. 44/55, en esp. pág. 52; y de Ibarlucía, Emilio A.: "Control de oficio de constitucionalidad. Algunas precisiones sobre su procedencia", El Derecho, diario del 09/05/2002, Bs. As., Rep. Arg., págs. 1/7, en esp. pág. 3. 
constitucional), desechando la de menor valor 29 . La confrontación de la norma inferior con la superior no es - ni podría serlo- totalmente aséptica ni mecánica (del tipo de colocar exclusivamente norma sobre norma prescindiendo de otros componentes extranormativos), sino que -como veremos infra- involucra otros importantes elementos fácticos, axiológicos - inter alia-30.

Es que, como subraya SAGÜEs, el principio de supremacía constitucional además de tener sustento normativo (cfr. el citado art. 31 de la C.N.), requiere sustento conductista, es decir, el comportamiento de los operadores de la Constitución y su voluntad de cumplirla, como de castigar las infracciones a tal supremacía ${ }^{31}$. Está claro que la custodia de tan elemental principio no podría - a riesgo de caer en un simplismo formalista impresentable- quedar supeditada a la mera petición de las partes en el proceso.

$Y$ ya que estamos refiriéndonos a la confrontación de una norma de valía inferior (infraconstitucional) con la jerárquicamente superior (de la Constitución), permítasenos una digresión.

Pareciera que la autoprohibición jurisdiccional de declarar de oficio la inconstitucionalidad de una norma contraria a la Ley Fundamental da la razón a Nino, cuando critica la aparente pulcritud de la denominada 'lógica de Marshall', al decir que para el mentor de la solución propiciada en 'Marbury' basta que una ley contradiga lo establecido por una norma constitucional válida para que no exista como tal, no tenga validez, carezca de fuerza obligatoria y no pertenezca al sistema jurídico; criterio que no corresponde a la fenomenología del pensamiento jurídico, ya que existen muchas leyes que contradicen objetivamente a disposiciones constitucionales $y$, no obstante, son consideradas como leyes válidas y obligatorias, situación que por ejemplo se configura antes de que sean declaradas

29 En un fallo interesante, $y$ entre otras cosas, se ha dicho que: "Si el Derecho es un sistema en el que las normas de menor jerarquía se nutren de las superiores, no se advierte cómo podría practicarse un corte horizontal del ordenamiento inmediatamente por debajo de la Constitución, de modo que, ante el silencio de las partes, los jueces resultaren aplicando el Derecho de menor nivel e ignorando el de mayor jerarquía" (T. Trab. N 4, La Plata, 11 de julio de 1997: "Alonso, Pedro c/ IN-DE-CO Minoli S.A.I.C.," fallo reseñado en AcKERMAN, Mario E. y MAZA, Miguel Á.: Ley sobre Riesgos del Trabajo. Aspectos constitucionales $y$ procesales. Digesto jurisprudencial $y$ normativo, RubinzalCulzoni, Santa Fe, Rep. Arg., 1999, pág. 114, N²97).

30 Sobre el punto, coincidimos con SAGÜÉS, Néstor P.: La interpretación judicial de la Constitución, Depalma, Bs. As., Rep. Arg., 1998, pág. 114.

31 SAgÜÉs, NÉSTOR P., en el prólogo al libro de BIANCHI, Alberto B.: Control de constitucionalidad, Ed. Ábaco, Bs. As., Rep. Arg., 1992, págs. 13/14. 
inconstitucionales por un juez, o respecto de efectos anteriores a tal declaración, $o$ en casos diferentes a aquel en que fueron calificadas de inconstitucionales, o si el magistrado se equivoca y considera constitucional a una ley objetivamente contraria a la Constitución, o si no existe un procedimiento para controlar la constitucionalidad de las normas o si, existiendo, éste no se ejerce en la práctica 32 , o si -añadimos por nuestra parte- el juez se autocensura y no procede a efectuar el control movido por la sumisión a la regla tácita que le marca que la inconstitucionalidad de una norma no puede ser declarada de oficio (en el caso, la norma no controlada, y aun cuando anticonstitucional, sigue siendo formalmente válida $y$ jurídicamente eficaz).

Este problema que Nino plantea con agudeza, fue enfrentado por Kelsen (a diferencia de MARSHALL), acudiendo a dos recursos teóricos -criticados por Nino-: el primero consistió en adoptar una posición subjetivista sobre la validez de las normas, sosteniendo que ésta dependía de que los jueces la declararan tal; el restante, radicó en su famosa 'cláusula alternativa tácita', por la cual, si se considera que una norma es válida y obligatoria en determinadas circunstancias no obstante contradecir una cláusula expresa de una norma válida superior, ello implica que el pensamiento jurídico está asumiendo que, al lado de dicha cláusula expresa, debe haber una tácita autorizando a que se sancione la norma inferior, a pesar de su contradicción con el texto explícito ${ }^{33}$.

4. Naturaleza y calibre de la presunción de validez de las normas y actos estatales

Tampoco resiste embate analítico alguno el argumento de que la declaración de inconstitucionalidad de oficio destruye la presunción de validez o constitucionalidad de las normas estatales, pues obviamente se trata de una presunción iuris tantum, es decir, desvirtuable, y en el supuesto de que el juez constate que la norma en cuestión resulta lesiva de la Constitución, la pretendida virtualidad presuncional deberá ceder frente a la obligación de mantener indemne la supremacía constitucional, sin olvidar que tampoco se entendería de qué modo dejaría de ser atentatoria de

32 Nino, Carlos S.: “Los fundamentos del control judicial de constitucionalidad," en la obra colectiva Los fundamentos $y$ alcances del control judicial de constitucionalidad, Cuadernos y Debates, $N^{\circ} 29$, Centro de Estudios Constitucionales, Madrid, España, 1991, págs. 101/102.

33 Ibíd., págs. 102/103. 
la mentada presunción la concreta petición de una de las partes en el proceso por la que reclamara expreşamente la declaración de inconstitucionalidad de la norma cuestionada 34 .

Desde nuestro punto de vista, la presunción de validez de las normas y actos estatales no implica una presunción de legitimidad, sino de legalidad. La norma o el acto pueden ser legales mas no legítimos, y entonces, aun cuando superen el test de legalidad (cumplimiento objetivo de la normativa vigente), deben ser declarados inconstitucionales si no lo hacen respecto de la prueba de legitimidad (coherencia entre lo enunciado en la norma y lo dado en la realidad o análisis de los efectos del precepto en su aplicación al específico caso sub lite), labor para cuyo cabal cumplimiento es absolutamente irrelevante si existe o no petición de parte. Aquel análisis de legitimidad entraña una vinculación axiológicamente más profunda (que incluye, por ejemplo, el examen de razonabilidad como fundamento de justicia) que la que se configura respecto de la legalidad, que -a nuestro juicio- se ciñe a la obediencia de la letra de la ley.

5. Alcance y proyección del debate jurisdiccional sobre la razonabilidad de las normas

Respecto de lo precedentemente afirmado en punto a que la verificación jurisdiccional de constitucionalidad deberia involucrar en el marco del examen de legitimidad a las consecuencias de la norma en su vivencia aplicativa al caso concreto, no se nos escapa -por cierto- el criterio sustentado por la Corte en diversos pronunciamientos, en el sentido de que el debate sobre la razonabilidad de una ley no puede llevarse a cabo sino en el ámbito de sus previsiones y de modo alguno sobre la base de los resultados posibles de su aplicación ${ }^{35}$ (subrayado nuestro). ${ }^{36}$

Pero si confrontamos tal afirmación de la Corte con la que, surgida de la misma fuente dimanante, expresa que las leyes resultan irrazonables

34 Cfr. SAGüEs, Néstor P.: "La prohibición de declarar de oficio la inconstitucionalidad de las normas (Un problema de sociología judicial)", La Ley, T 1981-A, Bs. As., Rep. Arg., pág. 846.

35 V.gr., Fallos, 299:45 ("Feito García de Carreira, María Isabel c/ Muñoz, Alberto").

36 Ver, entre otros trabajos de BAZÁn, Víctor: “Derecho Penal Tributario, test de razonabilidad y declaración de inconstitucionalidad de oficio", La Ley [Suplemento de Derecho Constitucional], Bs. As., Rep. Arg., 15/06/2001, págs. 12/22, en esp. págs. 18/21. 
cuando los medios que arbitran no se adecuan a los fines cuya realización procuran o cuando consagran una iniquidad manifiesta ${ }^{37}$ (énfasis añadido), nos parece que la frontera no es tan nitida como para distinguir matemáticamente las hipótesis en las que sería improcedente la declaración de irrazonabilidad de las que no lo sería. Es que, para cotejar si medios y fines legales son adecuados, habrá que determinar en la práctica los efectos que el precepto produce, lo que automáticamente nos llevaria a examinar los resultados posibles de su aplicación (y, eventualmente, un estudio de factores extranormativos) a un caso concreto, por cuanto no debemos olvidar que para que exista contralor de constitucionalidad debe mediar causa sometida a juzgamiento.

Además, tampoco nos parece coherente que no se permita la corrección judicial por la irrazonabilidad respecto de los resultados posibles de su aplicación y sí se la estime procedente cuando las leyes resulten irrazonables, pues -más allá de la coincidencia léxica entre el sustantivo empleado en la prohibición (resultados) y el verbo utilizado en la hipótesis permisiva (resulten)-, en ambos casos el tribunal deberá hacer mérito de las consecuencias o efectos que la norma puesta en crisis produce en el caso específico cuya solución jurisdiccional se le requiere (efecto o consecuencia $=$ resultado; que produce $=$ que resulta .

De cualquier modo, justo es reconocer que la Corte ha experimentado una morigeración de su rigidez perceptiva cuando de examinar la irrazonabilidad de una norma se trata, al haber puntualizado que "corresponde declarar la inconstitucionalidad de normas que -aunque no ostensiblemente incorrectas en su inicio- devienen indefendibles desde el punto de vista constitucional, pues el principio de razonabilidad exige que deba cuidarse especialmente que los preceptos legales mantengan coherencia con las reglas constitucionales durante el lapso que dure su vigencia en el tiem-

37 Por ejemplo, in re: "Azar, Juan Roberto" (Fallos, 299:428). Las concepciones permisiva y la prohibitiva a que aludimos en el texto, fueron también expuestas -ejemplificativamente- en "Mickey S.A." (del 5 de noviembre de 1991, considerandos $5^{\circ}$ y $6^{\circ}$. cuyo texto íntegro puede consultarse en Jurisprudencia Argentina, T' 1992-I, Bs. As., Rep. Arg., págs. 27/31), precedente en el que la Corte concluyó sosteniendo que los jueces deben expedirse por la legitimidad de la norma si tienen la certeza de que ella expresa fielmente "Ia conciencia juridica y moral de la comunidad". Esta última afirmación fue igualmente expuesta en "Abal, Edelmiro y otros c/ Diario 'La Prensa'" (Fallos, 248:291, considerando 24 -específicamente, en pág. 324-), manifestando el Tribunal in verbis: "Ningún acto judicial puede ser mantenido si sus más obvias inferencias hieren la conciencia jurídica y moral de la comunidad, manifestada en las normas y principios de la Constitución". 
po, de suerte que su aplicación concreta no resulte contradictoria con lo establecido en la Carta Magna»38; criterio que, en definitiva, fue el plasmado por el tribunal en la causa "Ricci» (vid. infra), específicamente en su considerando $4^{\circ}$, en tanto concreta un reenvío a los fundamentos de Fallos 316:310439, cuyo considerando 11 recepta textualmente la pauta hermenéutica transcripta. 40

\section{LA LÍNEA EVOLUTIVA DE LA JURISPRUDENCIA DE LA CORTE SOBRE EL CONTROL DE CONSTITUCIONALIDAD EX OFFICIO}

\section{Pórtico}

En orden a señalar la línea evolutiva de la doctrina judicial de la Corte sobre la declaración de inconstitucionalidad de oficio, es dable remarcar la existencia de ciertos eslabones importantes que denotan una quasi absoluta proscripción inicial $y$, luego, una posición prohibitiva constante -en líneas generales - aun cuando atemperada por determinados precedentes que permitieron alimentar la esperanza de un vasto sector doctrinario en el sentido de vivenciar el definitivo repliegue de una posición jurisprudencial tan prejuiciosa como carente de sustento.

Sea como fuere, lo cierto es que a partir de "Mill de Pereyra", la jurisprudencia de la Corte, al menos en cuanto al voto mayoritario se refiere, pareciera abandonar inequívocamente la renuencia en admitir la viabilidad del control de constitucionalidad ex officio.

\section{Fallos, 301:319 (considerando $6^{\circ}$ ); 316:3104 (considerando 11).}

39 Se trata de la causa "Vega, Humberto Atilio c/ Consorcio de Propietarios del Edificio Loma Verde y otro s/ accidente - Ley 9.688", resuelta en fecha 16 de diciembre de 1993 (Fallos, 316:3104).

40 Fuera y más allá del problema medular en torno del que gira este trabajo, tangencialmente diremos que, a los efectos de la visualización de las características del análisis de razonabilidad que realiza la Corte Suprema, no puede dejar de verse la solución dispensada en "Banco de Galicia y Buenos Aires s/ solicita intervención urgente en: "Smith, Carlos A. c. P.E.N. s/ sumarisimo"" (del 1 de febrero de 2002), mediante la que -inter alia- declaró la inconstitucionalidad del Decreto de necesidad y urgencia Nac. $N^{\circ}$ $1.570 / 01$ y de sus normas modificatorias y reglamentarias.

Al respecto, ver -por todos- el excelente trabajo de GELL, María Angélica: "EI caso "Smith" (o la razonabilidad cuestionada)", La Ley, T 2002-B, Bs. As., Rep. Arg., págs. $790 / 796$, en especial págs. $792 / 794$, en cuanto al examen de la razonabilidad de las leyes y los actos administrativos que restringen el ejercicio de los derechos constitucionales y los criterios para concretar tal análisis. 
Colateralmente, conviene decir que la reciente reforma constitucional de 1994 no ha zanjado la cuestión, pues si bien positivó algunos trascendentes procesos constitucionales (amparo, hábeas data y hábeas corpus ${ }^{41}$ ) a lo largo y lo ancho del nuevo art. $43^{42} \mathrm{e}$ incluyó expresamente en la parte in fine del primer párrafo de este precepto la posibilidad de que el juez del amparo declare la inconstitucionalidad de la norma en que se funden el acto o la omisión lesivos, no ha aclarado si aquél recepta o no habilitación para hacerlo de oficio 43 .

\section{Tesis prohibitiva}

A. En cuanto a los precedentes en los que se visualiza la tesis prohibitiva extrema, es imposible soslayar siquiera una breve referencia a un hito negativo y prejuicioso en el derrotero jurisprudencial de la Corte.

Nos referimos al caso "S.A. Ganadera Los Lagos" 44 (del 30 de junio de 1941), en el que a lo largo del considerando 12 dejó sentado que «es condición esencial en la organización de la administración de justicia con la categoría de 'poder', la de que no le sea dado controlar por propia iniciativa de oficio los actos legislativos o los decretos de la administración. Para mantener la supremacía de la Constitución y de las leyes sin provocar el desequilibrio de los tres poderes, es indispensable que exista en pleito

41 Colateralmente, es dable aclarar que la Ley Nac. $N^{\circ} 23.098$ de hábeas corpus (B.O. 25/10/84) plasmó, en su art. 6, la viabilidad de la declaración de oficio de inconstitucionalidad por los jueces, en caso concreto, cuando la limitación de la libertad se lleve a cabo por orden escrita de una autoridad que obra en virtud de un precepto legal contrario a la Constitución Nacional.

42 Ver, sobre el particular, BAZÁN, Víctor: "Sobre la cobertura tuitiva del hábeas data (especial referencia al derecho federal argentino)", Revista del Foro, Año LXXXVI, N 2, Colegio de Abogados de Lima, Perú, junio-diciembre de 1998, págs. 143/151.

43 En realidad, se ha literalizado una facultad jurisdiccional que venía explícitamente proscripta por el art. 2, inc. 'd', de la Ley Nac. No 16.986 de 1966 (regulatoria del amparo contra actos u omisiones de autoridad pública). Pese a tal prohibición, la Corte Suprema habia sentado jurisprudencia (con anterioridad a la reforma de 1994) en el sentido de que el contralor de constitucionalidad en el amparo era viable (ver, v.gr., sentencia emitida en el caso “Peralta, Luis A. y otro c/ Estado Nacional, Ministerio de Economia - BCRA", del 27 de diciembre de 1990 [El Derecho, T 141, Bs. As., Rep. Arg., págs. 519 y ss.]).

44 En relación con los antecedentes jurisprudenciales previos a la consolidación de la tesis negatoria, ver BAZÁN, Víctor: “La Corte, la declaración de inconstitucionalidad de oficio y el sendero hacia la superación de una doctrina judicial inconsistente", El Derecho, diario del 01/10/98, Bs. As., Rep. Arg., págs. 4/5. 
una cuestión que proporcione a los componentes del poder judicial la oportunidad de examinar, a pedido de alguno de los litigantes, si la ley o el decreto conforman sus disposiciones a los principios y garantías de la Constitución Nacional». Añadió la Corte -citando a CoOLEY- que "es indispensable un conflicto judicial y un peticionante cuyos derechos personales se encuentren realmente afectados. Sólo entonces la potestad legislativa y ejecutiva puede ser puesta en tela de juicio y tachada de ilegítima. Sin este freno el equilibrio de los tres poderes, condición esencial del gobierno organizado por la Constitución, se habría roto por la absorción del poder judicial en desmedro de los otros dos» 45 (bastardilla nuestra).

Previamente, en el considerando $8^{\circ}$ in fine, expresó la Corte que los actos administrativos que, «por serlo, tienen en su favor la presunción de constituir el ejercicio legítimo de la actividad administrativa $y$, por consiguiente, toda invocación de nulidad contra ellos debe necesariamente ser alegada y probada en juicio... [lo que] sucede cuando se han desconocido o vulnerado principios de derecho público o garantías individuales».

B. No abusaremos de la paciencia del lector explayándonos en los diversos casos en los que la Corte aplicó la directriz hermenéutica prohibitiva; sólo nos permitiremos citar algunos de ellos: «Recurso de revisión interpuesto por el penado Emilio Nasirn 46 (del 23 de julio de 1945); "Municipalidad de la Capital c/ Rodríguez, Pedro" 47 (del 31 de mayo de 1946); «Recurso de hecho deducido por la actora en los autos Lagos, Adolfo c/ Lagos, J. y otros» 48 (del 1 de julio de 1946); "Morales, Dionisio c/ Cánovas, Manuel y Eduardo»49 (del 11 de abril de 1956); "Roncoroni de Claisse, Élida Josefa c/ Uhart, Roberto Domingo s/ excepción prórroga art. $3^{\circ}$, incs. d), g) y j), Ley 14.451 "50 (del 15 de diciembre de 1961); “Montaña o Montagna, Inés Temporelli de c/ Consejo General de Educación y/o Prov. de Santa Fe y/u ocupantesTaller de Manualidades s/ desalojo " 51 (del 15 de marzo de 1967); "Sluzevsky, Jorge s/ jubilación» 52 (del 3 de noviembre de

\footnotetext{
45 Fallos, 190:142, en esp. págs. 155/156.

46 Fallos, 202:249.

47 La Ley, ${ }^{\circ} 42$, Bs. As., Rep. Arg., págs. $886 / 888$.

48 Fallos, 205:165.

49 Fallos, 234:335. Específicamente, la sentencia de la Corte Suprema corre transcripta entre las págs. 342 a 345 .

50 Fallos, 251:455.

51 Fallos, 267:150.

52 Fallos, 269:225.
} 
1967); «Meridiano, Soc. en Com. por Accs. c/ Administración Gral. de Puertos» 53 (del 24 de abril de 1979); «Martínez, Onoribal s/ cancelación ciudadanía» 54 (del 29 de noviembre de 1983); «Peyrú, Osvaldo Jorge»55 (del 2 de julio de 1987); etc.

De ellos, sólo evocaremos lo resuelto en el último de los casos nombrados ("Peyrú»), porque nos parece -dicho con todo respeto lo que sigueque es un ejemplo paradigmático de lo que no debería hacer un tribunal jurisdiccional. Veamos:

La Sala IV de la Cámara Nacional de Apelaciones en lo Contencioso Administrativo Federal -confirmando el fallo de su inferior en gradodeclaró la inconstitucionalidad del art. 10 de la Ley Nac. $N^{\circ} 21.898$, no obstante que tal tacha no había sido impetrada por el actor. El temperamento apuntado se sustentaba en la convicción de que a los jueces les asiste la facultad de declarar de oficio la ley penal cuando presente un vicio manifiesto, además de que la norma en crisis había sido descalificada constitucionalmente en constantes pronunciamientos de la Corte Suprema.

La sentencia de la alzada fue atacada por la representación fiscal a través del recurso extraordinario, el que, admitido, condujo a la revocación de la sentencia de $2^{\mathrm{a}}$ instancia a partir del criterio plasmado por la mayoría del tribunal, a pesar de la brillante disidencia de Fayt.

El detalle de los votos, dejando momentáneamente de lado el disenso de Fayt -sobre el que volveremos-, fue el siguiente: por la solución triunfante en definitiva, se expidieron Caballero y Bacqué. Por sus votos, lo hicieron Belluscio y Petracchi; aquél, mantuvo su posición favorable al control de constitucionalidad de oficio -tal como lo dejara sentado desde su disidencia compartida con Fayt en «Juzgado de Instrucción Militar $\mathrm{N}^{\circ} 50$ de Rosarion (ya citado)-, mas en el particular se expidió por la constitucionalidad del art. 10 de la Ley Nac. № 21.898, con lo que -por camino diversoarribó a idéntica solución que la mayoria; a su turno, Petracchi también propició dejar sin efecto la sentencia recurrida directamente en virtud de que juzgó constitucional el art. 10 de la ley retrocitada.

Pasemos a los argumentos que desnudan la visión mayoritaria reacia a la viabilidad del contralor de oficio, ámbito en el que se sostuvo que:

53 La Ley, T 1979-C, Bs. As., Rep. Arg., págs. 83 y ss.

54 Fallos, 305:2046.

55 Fallos, 310:1401. 
- Si bien la sentencia cuestionada alude a ciertos precedentes en los que la Corte declaró la inconstitucionalidad del art. 10 de la Ley Nac. No 21.898 (Fallos, 304:849; 304:1927; etc.), "con fundamentos que comparte en su actual integración (sentencias del 2/4/85; en autos F.152.XX., Faag, Astrid Nora v. Gobierno Nacional -A.N.A.- s/ demanda contenciosa; del 15/8/85, T-96-XX, Thompson S.A. s/ apelación; del 15/10/85, F.207.XX, Frigorífico Garina S.A. s/recurso de apelación) atendió con ello a la objeción constitucional oportunamente formulada por la actora, en tanto que ante la ausencia de dicho cuestionamiento en los autos concluyó que no era posible preterir la aplicación de la Ley 21.898 (Fallos, 305:294) „56 -considerando $3^{\circ}$-;

- además, reenvia a la doctrina sentada en Fallos, 190:142 («S.A. Ganadera Los Lagos»), en cuanto a que «es condición esencial en la organización de la administración de justicia con la categoría de 'poder' la de que no le sea dado controlar por propia iniciativa los actos legislativos o los decretos de la administración... [ya que] para mantener la supremacía de la Constitución y de las leyes sin provocar el desequilibrio de los tres poderes, es indispensable que exista en pleito una cuestión que proporcione a los componentes del poder judicial la oportunidad de examinar, a pedido de alguno de los litigantes, si la ley o el decreto conforman sus disposiciones a los principios y garantías de la Constitución Nacional»; y

- por fin, puntualiza que si los textos normativos en juego no han sido objeto de planteamiento y tacha de inconstitucionalidad por el afectado, no es dable expedirse de oficio al respecto (Fallos, 289:8957; 289:17758; 305:204659; 306:303 -ya aludido-l, excepto cuando se desborden los límites constitucionales de las atribuciones jurisdiccionales de la propia Corte (Fallos, $238: 288^{60}$ y sus citas).

56 Énfasis nuestro.

57 In re: "Nación Argentina c/ Loterszpil, Samuel" (sentencia del 28 de junio de 1974). Seguramente, el reenvío se refiere al considerando $7^{\circ}$ de este pronunciamiento.

58 Autos: "Editora Popular Americana S.R.L. (Diario 'El Mundo') c/ Nación Argentina" (del 6 de agosto de 1974). La remisión se dirige al considerando 13 de este fallo.

59 Autos: "Martínez, Onoribal" (del 29 de noviembre de 1983). Suponemos que el reenvío va en búsqueda del considerando $3^{\circ}$ de esta sentencia.

60 Se trata de la sentencia emitida en el caso "Partido Provincial Unión Santiagueña", del 19 de julio de 1957 (sobre la que volveremos), emitida en virtud del recurso ordinario de apelación contra el fallo de la Cámara Nacional de Apelaciones de Tucumán del 2 de abril de 1957. 
La poco laudable solución a la que llegó la Corte en el caso estudiado, validando una norma que ella misma declarara inconstitucional en otros precedentes y revocando la sentencia recurrida, fue atemperada de algún modo por la lúcida disidencia de Fayt $-y$, en líneas generales, por la persistencia del planteo de Belluscio en favor de la declaración de inconstitucionalidad ex officio-. Pasemos al voto disidente de Fayt:

- Tal magistrado procura poner en evidencia el error que consiste en pensar que la exigencia de que exista un caso judicial concreto para que quede habilitada la posibilidad de declarar la inconstitucionalidad, pueda limitar la facultad del juez de buscar, para las causas sometidas a su conocimiento, el encuadre normativo pertinente con prescindencia de las argumentaciones de las partes; facultad que no puede ser restringida cuando se encuentra en juego la C.N. (vid. considerando $6^{\circ}$ );

- que no debe confundirse el ejercicio del control de constitucionalidad de oficio efectivizado en el marco de una causa judicial, haya o no sido objeto de petición por el afectado, con la declaración de inconstitucionalidad en abstracto, es decir, fuera de un caso judicial concreto (considerando $9^{\circ}$ ); $y$

- que la facultad de garantizar la primacía de la C.N. es tanto propia de los jueces nacionales cuanto de los provinciales $y$, en particular, respecto de la justicia nacional, Fayt considera errónea (con sustento en los arts. 2 y 3 de la Ley Nac. $N^{\circ} 27$ ) la conclusión que imperara en la Corte (sentada en Fallos, 190:142) respecto de la expresión "de oficio", ya que dicho Cuerpo la asimila a "en abstracto" o "sin causa judicial» (considerando 10).

Creemos estéril extendernos en el comentario de la negativa impresión que nos merece la postura mayoritaria de la Corte en «Peyrú», por lo que sólo diremos - para finalizar-que el cartabón hermenéutico propiciado en tal caso vulnera -entre otros principios fundamentales- la propia igualdad jurídica de los justiciables ante las respuestas intercadentes expedidas por el tribunal. Sólo resta dejar flotando el siguiente interrogante-reflexión: ¿Es justo someter la vigencia de las garantías y derechos constitucio-

Precisamente en la parte final de "Partido Provincial Unión Santiagueña", la Corte alude a la excepción apuntada, remitiendo a Fallos, 143:191 (“El Gobierno de la Nación y la Unión de Fabricantes de Tejidos de Yute de España. Compromiso arbitral; sobre regulación de honorarios", del 6 de mayo de 1925); 185:140 ("Sociedad Comercial e Industrial Francisco Cores Ltda. c/ Provincia de Buenos Aires s/ inconstitucionalidad y repetición de pago", del 8 de noviembre de 1939); inter alia. 
nales a una circunstancia tan contingente como la mayor o menor pericia de los abogados de las partes en un proceso, de tal suerte que el tribunal sólo podrá marginar por inconstitucional una norma aplicable al caso si tal conducta le viene requerida expresamente por los litigantes?

La respuesta negativa fluye sin dificultad. La Corte estaba persuadida de la inconstitucionalidad de una determinada norma (incluso, así lo había declarado en varios precedentes), mas en el caso concreto se abstuvo de hacerlo (y revocó la sentencia del inferior que, cumpliendo su deber constitucional, había censurado por inconstitucional al mencionado precepto) por cuanto no medió requerimiento de parte en tal sentido.

\section{Algunos precedentes o votos refrescantes}

Por un sendero inverso al discurrido por la posición reacia de la Corte, justo es recordar en la línea evolutiva de su jurisprudencia algunos importantes jalones que marcaron, ejemplificativamente, los siguientes:

A. En Fallos, 11:257, puede detectarse un lejano antecedente acerca de la viabilidad del control de oficio61. Así, el Juez Seccional (en fecha 26 de octubre de 1871) sostuvo -en posición confirmada por la Corte Suprema62 que aunque no se hubiera opuesto la excepción de inconstitucionalidad del impuesto establecido por el contrato de noviembre de 1856 y en el que se fundaba la demanda (interpuesta por los señores Vicente Casares e hijos contra los señores Sívori y Schiaffino cobrándoles la suma de un mil doscientos ocho pesos con doce centavos fuertes por derecho de los faros de los Bancos Ortiz y Chico a los vapores italianos "Agnese", "Clementina" e "lsabella»), declarar en el caso la obligación de abonarlo sería dar eficacia a actos inconstitucionales con violación de la ley suprema que todos deben acatar, conspirando contra uno de los "objetos" (sic) de la justicia nacional, y proceder contra el art. 3 de la Ley de 16 de octubre de 1862 sobre Justicia Nacional, porque la Constitución de Buenos Aires, antes de organizarse definitivamente la unión nacional, era tan suprema en el territorio donde regía como lo era en ese momento la Constitución Nacional (considerando $6^{\circ}$ del fallo del Juez Seccional). En síntesis, la demanda fue rechazada y, como vimos, el fallo recibió confirmación por parte de la Corte.

61 Incluso, asi lo pone de manifiesto Vázquez en su voto concurrente en "Mill de Pereyra" (considerando $9^{\circ}$ ).

62 La Corte expidió su sentencia el 17 de febrero de 1872, expresando brevemente: "Vistos, por sus fundamentos se confirma con costas la sentencia apelada..." 
B. El pronunciamiento emitido en el caso "Acosta, Héctor c/ Crysf S.A.) (21 de junio de 1977) 63 , en el que el Tribunal admitió -según afirma BIDART CAMPOS, comentando el fallo- que una cuestión de constitucionalidad introducida recién en $2^{a}$ instancia fuera resuelta por la alzada en ejercicio de atribuciones constitucionales (arts. 31 y ex 67, inc. 11, de la C.N. -actual art. 75, inc. 12-). Señala el autor citado que, en la hipótesis, habria existido declaración de inconstitucionalidad de oficio porque aun cuando medió petición de parte, la misma fue extemporánea, lo que significa tanto como que no la hubo, porque lo que se pide o propone a destiempo se tiene por no pedido ni propuesto 64 , conclusión anclada en la siguiente fundamentación: “La Cámara y la Corte entienden que pudo emitirse en $2^{\mathrm{a}}$ instancia una declaración de inconstitucionalidad recién introducida en el. proceso al expresarse agravios, no tanto porque a cierta altura del proceso la promovió la parte interesada, sino porque el control de constitucionalidad forma parte inherente e indisoluble de la jurisdicción judicial y porque el juez lo debe llevar a cabo aunque nadie lo incite a hacerlo. De no ser así, la Corte habría dicho que la alzada excedió la medida del recurso y de su competencia y hubiera descalificado el pronunciamiento por arbitrariedad»65. Valga aclarar que los argumentos vertidos resultan -como veremos- perfectamente extrapolables al caso "Ricci» (que infra será brevemente colacionado).

Si bien lo decidido en "Acosta" provocó alguna euforia doctrinaria, cabe recordar que la Corte mucho tiempo antes habia ya resuelto algún precedente en dirección coincidente. Así, en «Fernández Nogueira, José c/ Yacimientos Petroliferos Fiscales s/ cobro de pesos" 66 (del 16 de diciembre de 1940), luego de rememorar el principio genérico que marca que la cuestión federal debe ser planteada en los escritos que establecen las bases de la litis contestatio (considerando $2^{\circ}$ ), puntualizó (en el considerando $3^{\circ}$ ) que "sin embargo, no siempre es posible proceder en esa forma; por lo cual debe admitirse que, excepcionalmente y por causa justificada, la cuestión federal puede ser planteada después de aquella oportunidad", para pasar a nominar los precedentes resueltos en idéntico sentido: Fallos, 153:31967;

63 EI Derecho, T 74, Bs. As., Rep. Arg., 1977, págs. 385/386.

64 BiDART CAMPOS, Germán J.: "¿Hacia la declaración de oficio de la inconstitucionalidad?", loc. cit. nota anterior.

65 ídem.

66 Fallos, 188:482.

67 In re: "Tobal y Cía. c/ Compañía Argentina de Navegación Nicolás Mihanovich Ltda. $\mathrm{p} /$ defraudación a la renta de Aduana. Recurso de hecho" (del 17 de diciembre de 1928), en cuyo considerando $4^{\circ}$ puede leerse que "aun cuando sea exacto, como lo ha 
$175: 26268 ; 176: 30169$. La importancia de la doctrina dimanante del pronunciamiento estriba en la pauta que la Corte intercala, aun a modo de excepción, y no tanto en el resultado concreto de la causa, puesto que concluyó "que la cuestión federal invocada por el actor para fundar el recurso extraordinario ha sido extemporáneamente introducida en el pleito" (considerando 10), ya que habiendo tenido ocasión de incorporarla antes de la sentencia de $1^{\mathrm{a}}$ instancia -en el alegato, si no hubiera omitido presentarlo-, "la ha planteado por vez primera en el memorial de expresión de agravios ante la Cámara Federal de Apelación" (considerando $9^{\circ}$ ).

C. Otros hitos sumamente importantes en el derrotero jurisprudencial de la Corte lo constituyen sin duda el premonitorio y laudable voto de Fayt y Belluscio in re: "Juzgado de Instrucción Militar N ${ }^{\circ} 50$ de Rosario"70; la reiteración de tal postura en la disidencia conjunta de ambos en: “Pérez,

declarado la jurisprudencia, que la cuestión federal, base del recurso extraordinario, puede plantearse en el escrito respectivo de expresión de agravios, esto debe entenderse cuando dicha cuestión no haya podido traerse a juicio en la oportunidad debida para que sea materia del litigio".

68 Caso "Cubas, Pablo c/ Reyes, F. R. y otros s/ cobro de pastaje" (del 3 de julio de 1936), en el que la Corte sostuvo (considerando $2^{\circ}$ ) “que es verdad que la cuestión federal debe ser planteada, por acción o excepción, en la primera oportunidad en que las partes pueden alegar el derecho que les ampara o en que apoyan sus pretensiones (...), pero como esa oportunidad no se presenta siempre con claridad al trabarse la litis contestatio, la Corte ha considerado que procede el recurso siempre que uen el pleito y no después de terminado éste por sentencia de última instancia, se haya puesto en cuestión la validez de las leyes locales como contraria a la Constitución Nacional» ( $T^{\circ}$ 160 , pág. 101)".

69 Causa “Barreiro Magariño, José - infracción a la Ley 346" (del 11 de diciembre de 1936), en la que la Corte reenvió (considerando $3^{\circ}$ ) a "Tobal y Cía." (cit. en nota 67 de este trabajo), añadiendo que "toda cuestión federal que tienda a fundar el recurso extraordinario debe promoverse en los escritos que establecen los términos o bases de la litis, y sólo por excepción y por causa justificada puede ser suscitada después, como cuando en la sentencia de $1^{\mathrm{a}}$ instancia se aplica una disposición legal o administrativa no citada por las partes durante la secuela del juicio y que, en concepto del litigante agraviado, ella está afectada de inconstitucionalidad y una vez alegada haya podido ser debatida suficientemente" (considerando $4^{\circ}$ ).

70 Sentencia citada en nota 11 (ver, en especial, considerandos $4^{\circ}$ y $5^{\circ}$ del voto conjunto de ambos magistrados). El sesgo inoculado a tal voto, coincide en lo sustancial con el criterio expuesto por Fayt en la disidencia que emitiera en la causa "Ricci" -que infra será objeto de una breve referencia-. 
María del Carmen y otros c/ Empresa Nacional de Telecomunicaciones"71; la disidencia de Fayt y el voto de Belluscio en el citado caso "Peyrú"; el voto de Fayt en "Antedoro, Antonio D. c/ Instituto Nacional de Previsión Social" (del 10 de diciembre de 1996) ${ }^{72}$; etc. ${ }^{73}$

D. En un meduloso trabajo, HaRo indica algunos casos excepcionales en los que la Corte (en general, fuera del ámbito del recurso extraordinario) escapó del principio general negatorio de la viabilidad del control de constitucionalidad de oficio, entre los que incluye las hipótesis en que estuvo en juego su propia competencia federal en el marco de los actuales arts. 116 y 117 de la C.N. (ex arts. 100 y 101) y existió -a criterio de la Corte- una extralimitación por parte de la reglamentación, viéndose desbordados los límites constitucionales de sus atribuciones jurisdiccionales 74 , v.gr.: Fallos, 185:140; 238:288 -inter alia-; precedentes que serán reseñados a continuación:

- En Fallos, 185:14075, la Corte expresó que la jurisdicción es de orden público, razón por la cual la suya no puede ser extendida, por el acuerdo ni por el silencio de las partes, a casos no comprendidos en la Constitución y en las leyes que la reglamentan (considerando $\left.4^{\circ}\right)^{76} ; y$

71 Fallos, 310:1090. En cuanto a la solución del caso concreto, la disidencia de Fayt y Belluscio postulaba la no descalificación de la sentencia que condenó al pago de las sumas reclamadas por los actores con sustento en el art. 66 de la Convención Colectiva de Trabajo $\mathrm{N}^{\circ} 165 / 75$, declarando de oficio la inconstitucionalidad del art. 2 , inc. ' $a$ ', de la Ley Nac. $N^{\circ} 21.476$.

72 Ver fallo in extenso en La Ley, T 1997-C, Bs. As., Rep. Arg., págs. 809 y ss.

La referencia que Fayt formula al tema que nos ocupa figura en el considerando $5^{\circ}$ de su voto.

73 Con anterioridad a tales precedentes, también puede computarse como un antecedente auspicioso el hecho de que la Corte dijera en el aludido caso "Nasir" (ver nota 46), que "es de doctrina y de jurisprudencia no entrar de oficio al análisis de esa cuestión [constitucionalidad del Decreto del 3 de agosto de 1944 del P.E.N.] salvo que su silencio importe que se cause agravio fundamental" -cursiva nuestra- (considerando $4^{\circ}$ ), dejando abierta una válvula para escapar excepcionalmente del criterio general impeditivo del control oficioso, en la medida en que se verifique la hipótesis descripta: causación de agravio fundamental.

74 HARO, Ricardo: "Perspectivas del control de oficio de constitucionalidad", en BAZÁn, Víctor [coordinador], op. cit. [Desafíos del...], págs. 131/132.

75 Ver nota 60 in fine.

76 Tal principio había sido sostenido, con anterioridad, en el mencionado precedente de Fallos, 143:191 (vid. nota 60), en el que la Corte consideró que su competencia originaria "ha sido taxativamente determinada por el artículo 101 [hoy art. 117 de la C.N.] de la Constitución y no puede ser ampliada ni restringida por las partes ni por la ley a diferencia. de la jurisdicción de apelación que será ejercida según las reglas y excepciones que prescriba el Congreso" (considerando $4^{\circ}$ ). 
- en Fallos, 238:288 -ya citado (nota 60)-, dijo la Corte que si bien es de principio que el control de validez de los actos de los demás poderes estatales no puede ejercerse de oficio por los jueces, hace excepción a él la hipótesis de que la reglamentación exceda los límites constitucionales de las atribuciones jurisdiccionales de la Corte $y$ en la medida necesaria para determinar su competencia (considerando $3^{\circ}$ ).

El autor recientemente citado menciona como otra hipótesis excepcional aquélla en la que, aun sin existir causa judicial, la Corte declaró la inconstitucionalidad del Decreto-Ley Nac. N ${ }^{\circ} 17.642 / 6877$ regulatorio de un régimen de enjuiciamiento común para los integrantes de los tribunales superiores de provincia y de los representantes del Ministerio Público que ante ellos se desempeñaban, expidiéndose a través de la Acordada del 7 de marzo de 1968 (Fallos, 270:85).

También puede mencionarse la Acordada del 2 de abril de 1945, sobre la Creación de la Cámara de Apelaciones del Norte, en la que se analizó la nota remitida por el poder ejecutivo por la cual se comunicaba al Tribunal el nombramiento del doctor Fernando Dupuy para desempeñar el cargo de vocal de la Cámara de Apelaciones del Norte con asiento en Resistencia, disponiendo la Corte no tomar juramento al mencionado profesional $y$ comunicar tal decisión al ejecutivo (Fallos, 201:239). Es de resaltar que en la opinión vertida por el entonces Presidente de la Corte, doctor Roberto Repetto, quedó en claro que la jurisprudencia reiterada de la Corte había resuelto que la inconstitucionalidad de las leyes y decretos sólo podía pronunciarse a petición de parte y no de oficio, "tal jurisprudencia sólo se aplica al ejercicio de las facultades judiciales y no al supuesto (...) de actividades derivadas del [entonces] art. 99 de la Constitución [hoy, art. 113], que autoriza a la Corte a dictar su reglamento y, por consiguiente, a fijar las condiciones con arreglo a las cuales ejercitará su facultad de tomar juramento a los funcionarios designados por el P.E. de hecho o de derecho".

En sentido coincidente, y por conducto del Acuerdo del 9 de febrero de 198478 , la Corte declaró, ex officio, inaplicable el art. 24 de la Ley Nac. $\mathrm{N}^{\circ} 22.192$-que la facultaba para la designación de los integrantes del Tribunal de Ética Forense de entre los abogados inscriptos en la matrícula-, en virtud de que juzgó que tal prerrogativa excedía notoriamente el espectro de atribuciones jurisdiccionales que la Constitución le confiere y

77 HARO, Ricardo; op. cit., pág. 133.

78 Fallos, 306:8. 
a las cuales debe ceñirse. Paralelamente, derogó los arts. 6 a 14 de la Acordada $\mathrm{N}^{\circ}$ 13/80 (Fallos, 302:14) y los arts. 18 y 19 de sus disposiciones transitorias.

Cabe consignar que por. Acordada $\mathrm{N}^{\circ} 42$, del 8 de octubre de 1991, el más Alto Tribunal federal declaró la nulidad del Decreto $N^{\circ} 2.071 / 91 \mathrm{del}$ poder ejecutivo nacional, que suspendía por un año la vigencia del art. 7 de la Ley Nac. $N^{\circ} 23.853$ (de autarquía del poder judicial79) y los efectos de todos los actos dictados al amparo de dicha norma. Asimismo, invitó al ejecutivo a expedirse en los términos de lo dispuesto en el art. 4 de la Ley Nac. $N^{\circ} 23.853$, que prevé la solución a adoptar cuando los ingresos producidos mediante la aplicación del régimen que establece, no cumplen con la expectativa existente al momento de formularse la programación de las erogaciones (Fallos, 314:948).

Por su parte, corresponde incluir en esta reseña a la Acordada $\mathrm{N}^{\circ} 45$, del 23 de noviembre de 1995, mediante la cual la Corte, abocada a analizar el alcance del art. 5 de la Ley Nac. $N^{\circ} 24.480$ (precepto que disponía que el "Centro Nacional de Informática sobre Detenidos y Extravíos de Personas", creado por tal ley, dependería del poder judicial de la Nación y estaría bajo la jurisdicción de la Corte), se expidió por la inaplicabilidad de ese artículo, señalando que "ninguna duda" cabía de que la función conferida por el mismo excedía notoriamente el marco de las atribuciones jurisdiccionales que la Constitución otorga al Tribunal y a las cuales debe ceñirse estrictamente en su accionar-considerando $4^{\circ}-$ (Fallos, 318:1772).

Para finalizar este catálogo enunciativo, aludiremos a la Acordada $\mathrm{N}^{\circ}$ 20, del 11 de abril de 1996, por medio de la que la Corte declaró la inaplicabilidad del art. 1 de la Ley Nac. $N^{\circ} 24.63180$, en cuanto deroga las exenciones contempladas en el art. 20, incs. ' $p$ ' $y$ ' $r$ ' de la Ley Nac. $N^{\circ} 20.628$ (t.o. por el Decreto Nac. $\left.N^{\circ} 450 / 86\right)$, para los magistrados y funcionarios del poder judicial de la Nación (Fallos, 319:24).

E. Es interesante reseñar brevemente lo resuelto por la Corte in re: "Ricci, Oscar Francisco Augusto c/ Autolatina Argentina S.A. y otro s/ Accidente - Ley 9.688"81, del 28 de abril de 1998.

\section{B.O. del 24/10/90.}

${ }^{80}$ Tal artículo (en su inc. 'a') derogaba, a partir del 1 de enero de 1996, las disposiciones del art. 20 de la Ley Nac. $N^{\circ} 20.628$ del Impuesto a las Ganancias, que declaraban exentos de dicho tributo a los sueldos de todos los jueces del Poder Judicial de la Nación y de los funcionarios judiciales que tuvieran asignadas retribuciones iguales o superiores a los jueces de primera instancia (inc. ' $p$ '), así como a los haberes jubilatorios y las pensiones que correspondían por las funciones cuyas remuneraciones estuvieran exentas en los señalados términos (inc. ' $r$ ').

81 El fallo in extenso puede ser consultado en EI Derecho, loc. cit. nota 44, págs. 1/4. 
El punto nodal de la cuestión a dilucidar por la Corte radicaba en la viabilidad de concretar el control de constitucionalidad en un supuesto en el que el recurrente había omitido introducir el caso federal en la primera oportunidad procesal a su alcance, debate que -pensamos- queda capturado en uno de más vasto calibre que apunta al discernimiento -bien que indirecto- de la potencial posibilidad jurisdiccional de declarar la inconstitucionalidad de oficio de una norma legal.

El Alto Tribunal entendió excepcionalmente admisible la introducción del caso federal en ocasión de la expresión de agravios, para evitar la frustración del acceso del justiciable hacia una solución que brindara protección a las garantias constitucionales que alegaba; todo ello, teniendo en consideración el tenor de los derechos en juego y las particularidades de la causa, en la que se ventilaba la integridad psicofísica del trabajador; solución que se veía favorecida por cuanto en otro precedente (Fallos, 316:310482) la cuestión constitucional alegada había sido definida por la Corte en sentido coincidente al invocado por el recurrente.

En síntesis, el tribunal declaró admisible el recurso extraordinario incoado y dejó sin efecto la sentencia resistida. Todos los jueces de la Corte coincidieron en la solución antedicha, aunque dos de ellos -Fayt y Boggiano- escogieron discurrir caminos diversos, a través del planteamiento de sendas disidencias, para arribar a la meta común, mas brindando una importante y valiosa argumentación en pro de la institucionalización del control de constitucionalidad de oficio.

En su meduloso voto disidente 83 -al que no podemos sino adherir-, Fayt señala -considerando $3^{\circ}$ - que:

- Los magistrados se encuentran facultados a declarar de oficio la inconstitucionalidad de las normas, bien que no en abstracto -es decir, fuera de una causa concreta-, para lo que no es necesaria la petición expresa de parte interesada;

- el contralor constitucional versa sobre una cuestión de derecho y no de hecho, por lo que la potestad jurisdiccional de suplir el derecho no invocado por las partes o invocado en forma errada, incluye el deber de mantener la incolumidad de la supremacía constitucional establecida en el art. 31 de la C.N., aplicando -en caso de colisión normativa- la de rango superior, esto es, la constitucional; y

82 Vid. notas 39 y 38.

83 Que, como anunciáramos, coincide sustancialmente con el voto que, en coautoría con Belluscio, emitiera in re: "Juzgado de Instrucción Militar $N^{\circ} 50$ de Rosario" (cit. en nota 11). 
- del precitado artículo constitucional se desprende "la facultad de los jueces de cualquier fuero, jurisdicción y jerarquía, nacionales o provinciales, de examinar las leyes en los casos concretos que se presentan a su decisión, comparándolas con el texto y la significación de la Constitución para averiguar si guardan conformidad a ella, absteniéndose de aplicarlas si las encuentran en oposición", lo que no puede quedar supeditado al requerimiento de las partes.

Por su parte, y del voto también disidente de Boggiano, puede extraerse como idea-fuerza de su planteo la necesidad de revisar el criterio de la Corte sentado en "S.A. Ganadera Los Lagos S.A.", sustentándose en los siguientes argumentos ${ }^{84}$ :

- La declaración de inconstitucionalidad sin solicitud de parte no entraña un avasallamiento de la judicatura sobre los restantes poderes del Estado, puesto que dicha tarea -de la esencia misma del poder judicial- involucra la función de controlar la constitucionalidad de las actividades de aquéllos en orden a mantener la supremacía de la Ley Fundamental (art. 31) -considerando $5^{\circ}-$, lo que constituye un deber del juez incluido en la facultad resumida en el adagio romano iura novit curia, ya que el control de constitucionalidad constituye una cuestión de derecho que si bien no puede ser declarada en abstracto, de ello no se sigue que la parte interesada deba requerir tal control en forma expresa para que el juez proceda a efectuarlo (considerando $6^{\circ}$ );

- la atribución-deber que poseen los tribunales de justicia -nacionales y provinciales- de examinar las leyes para verificar si se conforman o no a la Constitución y abstenerse de aplicarlas si se oponen a ella, entraña uno de los fines superiores y fundamentales del poder judicial y una de las máximas garantías con que se ha entendido asegurar los derechos consagrados constitucionalmente contra los abusos de los poderes públicos, atribución que deriva de la distinción entre los poderes constituyente $y$ legislativo ordinario que surge de la Constitución y que supone la necesaria subordinación de éste a aquél (considerando $7^{\circ}$ );

${ }^{84}$ Trama argumental que, en realidad, consiste en una reproducción de lo que tal juez manifestara en la disidencia planteada in re: "Banco Buenos Aires Building Society S.A. - Quiebra", del 21 de abril de 1998. El fallo puede ser consultado en La Ley, $T^{\circ} 1998$ E, Bs. As., Rep. Arg., págs. 236 y ss. 
- el control constitucional ex officio no afecta la presunción de legitimidad (sic) de los actos legislativos, desde que tal instituto es meramente provisional -iuris tantum- y cede en un sistema de contralor difuso como el argentino, frente a la verificación y declaración de invalidez de las normas por el poder judicial (considerando $8^{\circ}$ ). Tampoco implica una violación del derecho de defensa, pues -además de lo sostenido por Fayt y Belluscio in re: "Juzgado de Instrucción Militar $N^{\circ} 50$ de Rosario" (ya citado)- en el sub examine la accionada ha podido expedirse respecto de la validez de la norma cuya constitucionalidad se puso en juego, al momento de contestar los agravios en $2^{\mathrm{a}}$ instancia y en ocasión de responder el traslado del recurso extraordinario articulado (considerando $9^{\circ}$ ); $y$

- no obstante todo lo afirmado, la declaración de inconstitucionalidad es un acto de suma gravedad institucional, que debe ser considerado como la ultima ratio del orden jurídico, debiendo estarse -en caso de duda- en favor de su constitucionalidad; por tanto, sólo deberá ser declarada cuando la repugnancia de la norma inferior en su cotejo con la suprema, sea manifiesta y la incompatibilidad inconciliable (considerando 10).

\section{LA CAUSA “MILL DE PEREYRA, RITA AURORAY OTROS C/ PROVINCIA DE CORRIENTES"}

1. Resulta imprescindible señalar un importante jalón en el desarrollo evolutivo de la doctrina jurisprudencial de la Corte en relación con el tema. Nos referimos a la causa del epígrafe, dirimida -como anunciábamos- el 27 de setiembre de 200185.

En ella, el Alto Tribunal ha comenzado a mudar -al menos con el aval de una suerte de mayoría sui generis de sus componentes- su posición proscriptiva del control de constitucionalidad de oficio.

En ese sentido, y además de los mencionados ministros Fayt, Belluscio y Boggiano (los dos primeros han asumido desde hace bastante tiempo la posición contraria al criterio negatorio mayoritario de la Corte; uniéndoseles en fecha más reciente el ministro Boggianol, se ha acoplado

85 El pronunciamiento citado puede consultarse en La Ley, T²001-F, Bs. As., Rep. Arg., págs. 886/906. 
explícitamente Vázquez, con lo que abierta y expresamente, se llegaría a una suerte de "mayoría" de cuatro miembros.

2. En cuanto a los antecedentes del caso, valga recordar que, contra la sentencia del Superior Tribunal de Justicia de la Provincia de Corrientes que admitió la demanda articulada por jueces que reclamaron el cumplimiento de la garantía de intangibilidad de sus remuneraciones, la vencida dedujo recurso extraordinario que fue parcialmente concedido. En aquello que fue denegado, articuló el recurso de queja.

Cabe señalar que el máximo tribunal correntino había declarado, de oficio, la inconstitucionalidad de los arts. 7, 10 y 13 de la Ley Nac. $\mathrm{N}^{\circ} 23.928$, de convertibilidad del austral, y de la Ley Prov. $\mathrm{N}^{\circ} 4.558$, de consolidación de la deuda pública provincial, juzgando que la Provincia de Corrientes incurrió en incumplimiento de la garantia de incolumidad de las remuneraciones de los magistrados (arts. 143 de la Constitución local, que prácticamente reproduce el ex art. 96 de la Nacional-que con la reforma de 1994 sólo mudó su numeración mas no su contenido, convirtiéndose en el actual art. 110-).

Precisamente uno de los fundamentos del recurrente, en relación con el tema que nos convoca, radicaba en que la declaración de inconstitucionalidad de oficio de las normativas mencionadas violaba los principios de congruencia y defensa en juicio.

3. La Corte, por mayoría, rechazó la queja, declaró procedente el recurso extraordinario, revocó la sentencia y ordenó que los autos volvieran al Tribunal de origen para que, por quien correspondiera, se dictara nueva sentencia.

A continuación veremos, bien que sintéticamente, el detalle del despliegue de los respectivos votos (en mayoría, concurrentes y las disidencias parciales):

A. El voto triunfante (Fayt y Belluscio), en el considerando $9^{\circ}$, se remitió a la moción -reiteradamente aludida en este trabajo- de tales ministros emitida en Fallos, 306:303 ("Juzgado de Instrucción Militar $\mathrm{N}^{\circ} 50$ de Rosario", concretamente al considerando $5^{\circ}$ ), que descarta fundadamente y uno a uno los cuestionamientos que se realizan en torno a la hipótesis admisoria de la viabilidad del control ex officio. En otras palabras, replica las tachas relativas a la alteración del principio de equilibrio de poderes a favor del judicial, al atentado contra la presunción de validez de los actos y normas estatales, $y$ a la afectación del derecho de defensa en juicio.

Sin embargo, se formulan algunas precisiones en punto al alcance de tal facultad fiscalizadora oficiosa (véase el considerando 10): 
- El ejercicio de tal facultad en orden a la misión de mantener el imperio de la Constitución sólo puede considerarse autorizado en situaciones muy precisas, ya que su existencia no importa desconocer que la invalidez constitucional de una norma sólo puede ser declarada cuando la violación de aquélla sea de tal entidad que justifique la abrogación, en desmedro de la seguridad jurídica (lo que supone un reenvío al considerando 19 del voto de los precitados jueces en Fallos, 306:303); y sólo será procedente cuando no exista la posibilidad de una solución adecuada del juicio por otras razones que las constitucionales comprendidas en la causa (Fallos, 260:153, considerando $3^{\circ}$ y sus citas);

- su ejercicio no supone en modo alguno la admisión de declaraciones en abstracto, es decir, fuera de una causa concreta en la cual debe optarse entre la aplicación de una norma de rango inferior en pugna con la C.N. o de ésta, a los efectos de resolver un conflicto contencioso en los términos del art. 2 de la Ley Nac. $N^{\circ}$ $27^{86}$ (considerando $4^{\circ}$ del voto de los mencionados jueces en Fallos, 306:303);

- este tipo de declaración de inconstitucionalidad ostenta alcance incidental, de allí que sólo será necesaria para remover un obstáculo -la norma inconstitucional- que se interponga entre la decisión de la causa y la aplicación directa a ésta de la Ley Fundamental, es decir, que la declaración será el presupuesto para el progreso de otra pretensión (causa A.529.XXII. "Asociación Bancaria c/ Provincia del Chubut", sentencia del 15 de junio de 1989) o, en su caso, defensa; $y$

- por último, que debe tenerse presente que con arreglo a la doctrina de la Corte las decisiones que declaran la inconstitucionalidad de la ley sólo producen efectos dentro de la causa y con vinculación a las relaciones jurídicas que la motivaron y no tienen efecto derogatorio genérico (Fallos, 247:700; 248:702; 255:262; 264:364; 315:276; 322:528, entre otros).

B. En su voto concurrente, Boggiano -entre los considerandos $9^{\circ}$ a 15- reitera los fundamentos que volcara en su moción disidente plasmada en la causa "Ricci" (vid. supra).

$86 \mathrm{Ver}$, al respecto, la aclaración que efectuáramos en la parte final del ap. I del presente trabajo. 
C. Resulta muy importante señalar que Vázquez, en su moción en concurrencia (considerandos $9^{\circ}$ a 21), vehicula una nueva adhesión interna de los componentes de la Corte a la procedencia del control oficioso de constitucionalidad.

En primer lugar, y luego de efectuar una disquisición en torno de la naturaleza de la Corte como tribunal judicial y como poder que ejerce una de las funciones del poder estatal (teniendo a su cargo, como órgano de gobierno, funciones políticas) -considerandos 10 y $11-$, pasa a justificar la nueva doctrina que postula (admisoria del control de oficio) sosteniendo que la autoridad de los precedentes debe ceder ante la comprobación de la inconveniencia del mantenimiento de resoluciones anteriores -considerando 12- (cfr. voto de los jueces Nazareno y Moliné O'Connor en Fallos, 317:312).

A continuación, expone que en la cita que a COOLEY efectuara el Tribunal en "Ganadera Los Lagos", éste omitió mencionar cuál era la obra de aquél que consultaba, además de afirmar el magistrado cuyo voto se recrea que el pensamiento de tal autor norteamericano no fue tan categórico como parece (considerando 14).

Por lo demás, se entregó a descartar los fundamentos empleados por la Corte en el caso mencionado en último término, a saber: que el control de constitucionalidad de oficio resulta contrario a la presunción de legitimidad de los actos del Estado -considerando 15-(Fallos, 234:335); que la facultad que tiene todo juez de seleccionar el derecho aplicable al caso no autoriza la declaración oficiosa de inconstitucionalidad-considerando 16-; y que el control oficioso implica una violación del derecho de defensa -considerando 17-.

Además, puso de manifiesto que la posición prohibitiva suscita notables contradicciones con otras decisiones de la Corte (considerando 18), por ejemplo, la que se plantea entre la correspondiente a Fallos, 319:2925 (en la que descalificó la sentencia de un SuperiorTribunal de Provincia por haberse abstenido de declarar de oficio la inconstitucionalidad de una ley local por ser contraria a una ley nacional) y la de la multicitada causa "Ganadera Los Lagos" (doctrina prohibitiva).

D. Desde nuestro punto de vista, López y Bossert admitieron implícitamente el control oficioso o, al menos, no lo descartaron tan firmemente como Moliné $O^{\prime}$ Connor o, con un poco menos de profusión argumental, como Nazareno y Petracchi, puesto que estimaron que la pretendida violación de la garantía de defensa en juicio (una de las principales máculas que se enrostra a la declaración de inconstitucionalidad de oficio) no se configura en tanto aquélla aparece resguardada dado que los litigantes tuvieron 
suficiente oportunidad de ser oídos sobre el punto (esto es, acerca de la norma invalidada sin petición de parte) en el remedio federal y su escrito de contestación (considerando $9^{\circ}$ ).

Naturalmente que la interpretación que ofrecemos (tratando de inteligir la posición de López y Bossert) se circunscribe a que la supuesta admisión que con optimismo intuimos acerca de la viabilidad de la hipótesis oficiosamente controladora quede ceñida a los jueces inferiores de la Nación o los jueces provinciales, mas no sería operable pensándola en términos de su ejercicio por parte de los ministros de la Corte Suprema, por cuanto si éstos declararan la anticonstitucionalidad en un caso concreto recién al emitir su sentencia, se supone que no habría existido posibilidad material para que las partes se hubiesen expedido respecto de la normativa en juego, al momento de sustentar o replicar, respectivamente, el recurso extraordinario en cuestión.

Contrariamente, y desde nuestra perspectiva, las posiciones asumidas desde hace tiempo por Fayt y Belluscio, más recientemente por Boggiano y últimamente por Vázquez, sí supondrian la autohabilitación de control ex officio de constitucionalidad respecto de la propia Corte Nacional.

E. Por último, Nazareno y Petracchi, en disidencia parcial, sostuvieron que de conformidad con antigua doctrina de la Corte, los jueces no están facultados para declarar de oficio la inconstitucionalidad de las leyes (Fallos, 282:15; 289:89; 303:715; 305:302 y 2046; 306:303; 310:1090 y 1401; 311:1843, entre otros) -considerando $7^{\circ}-$.

F. En sentido similar, mas con remisión a mayor cantidad de precedentes de la Corte y añadiendo algunas pautas para ilustrar su (contundente) negativa a proporcionar andamiento al control de constitucionalidad de oficio (con citas de COOLEY y LOEWENSTEIN -inter alia-), se pronunció Moliné O'Connor en su disidencia parcial. Este ministro deja a salvo -claro está- que de tal doctrina negatoria sólo cabe prescindir cuando la norma cuestionada afecta la autonomía funcional del poder judicial, se trata de reglamentaciones legales que exceden las atribuciones jurisdiccionales de los tribunales, o cuando la Corte hace ejercicio de las facultades derivadas del art. 113 de la C.N. (Fallos, 185:140; 238:288; 306:8; 314:948; 318:1772) -considerando $7^{\circ}-$.

G. En suma, y a modo de balance preliminar, pareciera que con «Mill de Pereyra" asistimos al comienzo del definitivo final de la posición mayoritaria de la Corte reacia a dar curso al control de constitucionalidad de oficio. Ojalá que el criterio admisorio de tal alternativa fiscalizatoria finalmente se cristalice y consolide. 


\section{SOBRE LAS MUTACIONES EN LA CONFORMACIÓN DE LA CORTE LUEGO DE "MILL DE PEREYRA"}

Para intentar proporcionar una visión actualizada del criterio de la. Corte en torno del tema, nos vemos precisados a advertir que, con posterioridad al dictado de sentencia en "Mill de Pereyra", se produjeron algunos hechos que conviene colacionar porque naturalmente tendrán incidencia directa sobre el modo de computar dicha posición judicial tanto en el presente cuanto en prospectiva.

En primer lugar, debe mencionarse la dimisión de Bossert y el ingreso de Maqueda. Asimismo, la renuncia de Nazareno, y la cobertura de su lugar con la entrada de Zaffaroni.

Por su parte, y aunque sólo cuente estadísticamente para decodificar su criterio, pues -como veremos- se alejó del cargo, López publicó un artículo de doctrina en el que fijó, con firmeza, su óptica favorable al control ex officio y advirtió que ése fue el sentido de su voto en "Mill de Pereyra"87. Precisamente al renunciar López, el Poder Ejecutivo Nacional ha lanzado la candidatura de la doctora Argibay para llenar la vacante. Por fin, debe manifestarse que el Congreso Nacional destituyó por medio de juicio político a Moliné $O^{\prime}$ Connor, aunque el Poder Ejecutivo aún no ha propuesto postulante alguno para suplantarlo.

Para clarificar lo que puede aparecer como una situación "críptica", por el momento el Tribunal cuenta con sólo siete de los nueve integrantes establecidos legalmente: Belluscio, Boggiano, Fayt, Petracchi, Vázquez, Maqueda y Zaffaroni. Los restantes dos lugares deben todavía ser cubiertos por el mecanismo fijado constitucionalmente: designación por el Poder Ejecutivo 88 con acuerdo del Senado (cfr. art. 99, inc. $4^{\circ}$ ).

87 LOPEZ, Guillermo A.F.: “El control de constitucionalidad de oficio", La Ley, 28/10/2002, Bs. As., Rep. Arg., págs. 1/3.

Entre otras cosas, dijo: "Deseo aclarar que mi postura (...) ha sido y es a favor de la declaración de inconstitucionalidad de oficio de manera amplia y no restringida" -énfasis añadido- (op. cit., págs. 3 y 4).

88 Sobre el punto es útil mencionar el dictado del Decreto Nac. № 222 de 2003, por medio del cual el Poder Ejecutivo "autorrestringió" las potestades contenidas en el art. 99, inc. $4^{\circ}$, de la C.N. Dicho decreto permite una cierta participación de la sociedad civil al habilitar el planteo, fundado, de impugnaciones a la postulación del candidato propuesto por el Poder Ejecutivo para integrar la Corte Suprema. Luego de todo ello, y en su caso de resueltas las articulaciones impugnativas, el Presidente decidirá si en definitiva envía o no al Senado de la Nación el pliego del postulante originariamente elegido. 
Con los movimientos expuestos, un corte transversal del criterio actual del Tribunal respecto del control constitucional oficioso daría como resultado la presencia de una polarización de fórmulas, matizada con un dejo enigmático en relación con la visión de algunos de sus integrantes:

- Por un lado, cuatro ministros admiten y se pronuncian a favor de la viabilidad de dicha alternativa fiscalizatoria: Fayt, Belluscio, Boggiano y Vázquez;

- por otro, un magistrado se expide claramente por la negativa: Petracchi, actual Presidente de la Corte; y

- los restantes miembros del Tribunal, ministros Maqueda y Zaffaroni, aún no se manifiestan judicialmente sobre el particular -al menos hasta donde llega nuestra información-, con lo cual se abre la incógnita en torno a si pasarán a engrosar el cuarteto que encarna la posición afirmativa o la postura negatoria que en solitario defiende Petracchi.

Obviamente, también habrá que ver cuál será la posición a asumir por los nuevos integrantes del Tribunal que vendrán a cubrir las vacantes provocadas por el alejamiento de López y la remoción de Moliné O'Connor, aunque este último todavía está dando pelea judicial al haber acudido a la Comisión Interamericana de Derechos Humanos para plantear su caso e intentar revertir la decisión destitutoria.

\section{OBSERVACIONES FINALES}

1. Sea como fuere que continúe delineándose el itinerario de la declaración de inconstitucionalidad de oficio en la perspectiva de la Corte, y aunque íntimamente hacemos votos por la continuidad aplicativa genérica de la solución que en "Ricci" y complementaria y contundentemente en "Mill de Pereyra" brindó -por mayoria- el Alto Tribunal federal ly la saludable doctrina emergente de ciertos sustanciosos votos, ya disidentes, ya concurrentes, formulados por algunos de sus integrantes en fallos anteriores), dichos precedentes permiten abrigar esperanzas en el sentido de que se alejará definitivamente el desacertado criterio de imposición de una especie de sui generis self-restraint ${ }^{89}$-que no surge explícita ni implíci-

89 Pensamos que ello implica una autodetracción injustificada al propio plexo competencial de la judicatura. Para ampliar, vid. BAZÁN, Víctor: "Sobre las denominadas cuestiones no judiciables y las detracciones injustificadas al Poder Judicial", en el libro 
tamente de la Ley Fundamental ni de la normativa infraconstitucionalrespecto del mandato imperativo que se cierne sobre todo magistrado judicial de inaplicar las normas refractarias a la Constitución, procediendo a su previa declaración de inconstitucionalidad, medie o no petitorio de las partes.

Es que fuera y más allá del provecho particular de éstas, se erige el prioritario interés general -que debe ser resguardado jurisdiccionalmente- de mantener la incolumidad de la Constitución, lo que en modo alguno implica que desde estas líneas alentemos un deslizamiento hacia el otro extremo del continuum, propiciando una "hiperinflación" de declaraciones de inconstitucionalidad al influjo de la irreflexividad o de la irresponsabilidad, lo que conduciría a una banalización de tan trascendente faena a cargo del poder judiciario.

2. En puridad, ninguno de los fundamentos que se brindan para dar apoyatura a la proscripción de examinar de oficio la constitucionalidad de las normas (peligro de absorción de los poderes ejecutivo y legislativo por el judicial, con el consecuente demérito del equilibrio de los poderes del Estado; atentado contra la presunción de validez de los actos y normas estatales; y vulneración del derecho de defensa en juicio de las partes) resultan totalmente sustentables y decisivos.

En efecto, la supremacía constitucional es una cuestión de derecho y de orden público; la presunción de legalidad de los actos y normas estatales es provisional y desvirtuable; y no existe agravio posible a la garantía constitucional de defensa en juicio para las partes puesto que la primacia de la Ley Fundamental, al ser indisponible para ellas, provoca que su requerimiento sea inidóneo para oficiar como elemento determinante de la actividad jurisdiccional cuando de desechar normas contrarias a la Constitución se trate. Vinculado con esta última cuestión, la omisión de peticionar la impugnación de inconstitucionalidad en que las partes en el proceso incurrieren, no debe operar como presunción de renuncia a los derechos subjetivos que pudieran estar lesionados y que los omitentes titularizan 90 .

colectivo Temas de Derecho Administrativo, ${ }^{\circ}$ III, Foro de Abogados, San Juan, Rep. Arg., págs. 183/204.

90 BIDART CAmpos, Germán J.; op. cit. [La interpretación y el control...], pág. 154.

Se advierte en ello la presencia y el fluir, por ejemplo, del texto y el espíritu del art. 874 del Código Civil. 
3. Ferrajol puntualiza que la tesis del iuspositivismo dogmático que afirma que para el juez existe una obligación jurídica de aplicar las leyes vigentes, no es del todo verdadera - al menos en los Estados de Derecho dotados de una constitución rígida [como es el caso de nuestro país, aun cuando - quizás - mitigada tal rigidez postreforma de 1994]-, dado que "cuando las leyes vigentes son sospechosas de invalidez, no existe ni siquiera para los jueces - incluso aun menos para los jueces- una obligación jurídica de aplicarlas", ya que al discernirse en éstos el poder de interpretarlas y de suspender su aplicación si las consideran inválidas por contrastar con la Constitución, mal puede decirse - en rigor- que tengan la obligación jurídica de aplicarlas ${ }^{91}$.

Añade el autor citado que la circunstancia de que una ley se encuentre vigente sólo significa que está contenida en un texto legislativo no anulado, pudiendo - por ende - ser aplicada mediante decisiones válidas respecto de ella, lo que no quita que pueda, igualmente, no ser aplicada cuando el juez la considere inválida; subraya que, en este último caso, debería decirse más bien que el juez "debe no aplicarla si no se tratase de un deber puramente potestativo, es decir, dependiente del juicio de invalidez formulado por él mismo" [énfasis del original] ${ }^{92}$. Si el deber jurisdiccional de no aplicación existe (como pensamos así es), no aparece razonable condicionar su cumplimiento a la convergencia de un pedimento de parte.

Con elocuencia, SAGÜÉS ha afirmado que "la tesis negativa podrá ser cualquier cosa, menos lógica"93. A su tiempo, BIANCHI ha llegado a catalogar de "mito" al principio de inhabilitación judicial para ejercer el control de constitucionalidad sin requerimiento de parte interesada 94 , manifestando que - como todo mito - tiene una buena dosis de irreflexión, entraña un cierto temor frente a su transgresión, siendo ese elemento "casi sobrenatural" el que le ha permitido entronizarse y pervivir por mucho tiempo;

91 FERRAJOLI, Luigi: Derecho y razón [Teoría del garantismo penal], $2^{\mathrm{a}}$ ed., Trotta, trad. de Perfecto Andrés Ibáñez, Alfonzo Ruiz Miguel, Juan Carlos Bayón Mohino, Juan Terradillos Basoco, Rocio Cantareros Bandrés; Madrid, España, 1997, págs. 872/873.

92 lbíd., pág. 873.

93 SAGÜÉs, Néstor P.; op. cit. ["El control de constitucionalidad de oficio. Alternativas..."], pág. 1.

94 El título del trabajo de BAZÁN, Víctor: “Desmitificando la prohibición de ejercer el control de constitucionalidad de oficio en el orden federal argentino", Revista Peruana de Derecho Constitucional, № 2, Tribunal Constitucional, Lima, Perú, 2000, págs. 301/321; obedece a una paráfrasis de la concepción del "mito" a que ha sido elevado el principio proscriptivo, de acuerdo con la percepción de BIANCHI (BIANCHI, Alberto B.; op. cit. en nota 31 , págs. 207/208). 
afirmación que - por cierto - no lo lleva a descartar otros ingredientes humanos como los anteriores, pero más "pedestres", como son la "pereza judicial" en examinar la legitimidad de una ley cuando ello no le ha sido peticionado, o la "comodidad y tranquilidad" que aparejan el hecho de no entrometerse en los asuntos de los poderes políticos si el juez no ha sido expresamente llamado a ello 95 .

4. Para concluir, pensando en términos retrospectivos y proyectándolos prospectivamente, pareciera que con "Mill de Pereyra" se asiste al comienzo del definitivo final de la posición mayoritaria de la Corte renuente a dar curso al control de constitucionalidad de oficio $y$, paralelamente, a la consecuente marcha hacia la consolidación del criterio admisorio de tal alternativa fiscalizatoria. Esperemos que así sea.

95 BIANCH, Alberto B.; idem, nota anterior parte final. 